Article

\title{
Does Vocational Education Give a Labour Market Advantage over the Whole Career? A Comparison of the United Kingdom and Switzerland
}

\author{
Maïlys Korber ${ }^{1,2}$ \\ ${ }^{1}$ Life Course and Inequality Research Centre, University of Lausanne, 1015 Lausanne, Switzerland; \\ E-Mail: mailys.korber@gmail.com \\ 2 Swiss National Centre of Competence in Research LIVES, University of Lausanne, 1015 Lausanne, Switzerland
}

Submitted: 26 February 2019 | Accepted: 20 June 2019 | Published: 5 September 2019

\begin{abstract}
Research suggests that vocational education and training (VET) tends to reduce youth unemployment by providing them with specific skills, thus smoothing the transition from education to work. However, we still know relatively little about whether vocational education provides higher employment rate and wages over the entire working trajectory than holders of lower education; after several years of experience, both groups may indeed have similar skills and thus similar situations in the labour market. We compare the situation in the United Kingdom and Switzerland, two countries that share a tradition of vocational education but differ in the specificity and standardisation of their VET system. Creating a pseudo-cohort with repeated rounds of the United Kingdom and Swiss labour force surveys, we use regression models and compare the employment rate and hourly wage of our two groups of interest: individuals with vocational education at the upper secondary level and individuals with no more than compulsory education. We find that VET graduates fare better in terms of both employment and wages over the whole career. This advantage is larger for women than men and, contrary to our hypothesis, larger in the United Kingdom than in Switzerland with respect to employment prospects.
\end{abstract}

\section{Keywords}

apprenticeship; earnings; employment; life course; Switzerland; United Kingdom; vocational education and training

\section{Issue}

This article is part of the issue "Types of Education, Achievement and Labour Market Integration over the Life Course", edited by Irene Kriesi (Swiss Federal Institute for Vocational Education and Training, Switzerland) and Juerg Schweri (Swiss Federal Institute for Vocational Education and Training, Switzerland).

(C) 2019 by the author; licensee Cogitatio (Lisbon, Portugal). This article is licensed under a Creative Commons Attribution 4.0 International License (CC BY).

\section{Introduction}

Vocational education and training (VET) has several advantages, both at the individual and country level. By providing vocational skills that are immediately useful in a company, entry into the labour market is eased and thus helps to reduce youth unemployment (OECD, 2010). Furthermore, practice as an important part of the learning process helps to increase motivation, which makes VET an interesting solution to provide education until the upper-secondary level to youth who have less interest or ability for academic education (Wolter \& Ryan, 2011). VET is thus seen as a solution against both educational drop-out and youth unemployment.

In scientific literature, VET is often compared with general education to address the question of advantages and disadvantages of the former. In this article, we propose a different approach and compare holders of an upper-secondary VET degree with holders of lower levels of education-i.e., compulsory education or lower. While the comparison of VET with general education is conceptually interesting, it is questionable whether having followed the academic track is the realistic counterfactual of having obtained a VET degree. If VET is chosen due to low school abilities or interest, as argued in the "safety-net" concept (Arum \& Shavit, 1995; Shavit \& Müller, 2000a), it seems plausible that the alternative would be the absence of upper secondary education and not the academic track.

The comparison of VET graduates with holders of lower education is especially interesting taking the lifecourse dimension into account. While we can expect a 
smooth entry into the labour market for VET graduates (OECD, 2010; Shavit \& Müller, 1998) and a more difficult one for holders of lower education, it is an open question whether the expected advantage of VET graduates in the labour market persists over the career, and whether it decreases or increases. To address this question, we use a pseudo-cohort design by pooling labour force survey data from more than twenty years. This enables us to follow a group of people born during a similar period (1954-1968) from the age of 25 to the age of 60 . Contrary to other articles using only one wave of crosssectional data to study whole careers (Forster, Bol, \& van de Werfhorst, 2016; Hanushek, Schwerdt, Woessmann, \& Zhang, 2017), we thus do not need to make the assumption that the situation of older individuals is a good proxy for the situation of younger people's futures.

Finally, we are interested in the possibility that the labour market returns to VET may vary depending on the context. Indeed, labour market prospects may depend on the country and especially the level of standardisation of the VET system. A more standardised VET system may increase the transferability of competences between employers and thus the capability for holders of a VET certificate to reach better positions (Bol \& Van de Werfhorst, 2013). On the contrary, a less standardised VET system may provide VET graduates with a set of skills that is similar to work experience in a firm, resulting in smaller differences between holders of a VET degree and people with a lower level of education. We address these questions by comparing the labour market outcomes between a country with a large and nationally standardised VET system-Switzerland-and a country with a less widespread and less standardised vocational system-the United Kingdom-using the UK Labour Force Survey 1993-2014 and the Swiss Labour Force Survey 1991-2014.

\section{Theoretical Framework and Hypotheses}

\subsection{Vocational Education versus Lower Education}

In order to address the question of whether VET provides positive labour market outcomes over the entire career, we need to determine the comparison group, or counterfactual. In the existing literature, VET is often compared to general education at a similar level (Brunello \& Rocco, 2015; Cörvers, Heijke, Kriechel, \& Pfeifer, 2011; Forster et al., 2016; Hanushek et al., 2017). However, holders of VET tend to perform worse, on average, at compulsory school than holders of general diplomas, even in countries, such as Switzerland, where VET is well recognised (Wolter et al., 2014, p. 119). This explains why VET is often considered as a good solution to provide uppersecondary education to youth who are less motivated or less able to follow an academic track after compulsory school (Wolter \& Ryan, 2011). VET then serves as a "safety-net" against school drop-out (Arum \& Shavit, 1995; Shavit \& Müller, 2000a). As a consequence, individ- uals with no more than one year of education after compulsory education (described thereafter as "lower education") may provide a relevant counterfactual for a VET diploma. This comparison group also presents the advantage of being highly comparable among countries.

\subsection{Vocational Education versus Work Experience}

Several studies have shown that vocational education facilitates entry into the labour market (e.g., Breen, 2005; Müller \& Gangl, 2003; Shavit \& Müller, 1998). One reason for the successful transition from education to work is that the content of the training is designed in close cooperation with employers. VET programmes tend to teach skills that are directly applicable, and thus correspond well to labour market demand. After the end of their training, workers are seen as immediately productive and, for this reason, can expect to find a job (almost) as easily as more experienced workers (Shavit \& Müller, 2000 a, p. 36). VET aims to bring practical skills to students by providing them an occupation or trade. It has the advantage of giving youth the opportunity to acquire skills that are useful for the labour market in real situations. This is especially the case in dual (work-based) programmes, also called apprenticeships, where young workers not only learn technical skills, such as cutting someone's hair or installing a heating system, but also learn how to interact with customers, colleagues, and supervisors. Indeed, apprentices spend part (or most) of the time working for a firm or organisation that trains him or her.

However, education is not the only way of acquiring skills. As argued in the literature about workplace learning, workers extend their capabilities through their work (Boud \& Garrick, 1999). Work experience should indeed provide employees with opportunities to learn new aspects of the job and to master them better over time. This idea is in line with the human capital theory (Becker, 1962), which presents work experience as an integral part of human capital. Since both VET and experience provide work-related skills, it is an open question whether, after several years of work experience, vocational education still provides an advantage over workers without post-obligatory education in terms of labour market outcomes such as employment and wages. While VET tends to ease labour market entry and reduce the risk of unemployment at the beginning of the career (e.g., Breen, 2005; Ryan, 2001), the advantage of obtaining a better-paid position after several years of experience is not evident. Shavit and Müller (2000b, p. 437) thus argue that [vocational education at the upper-secondary level] "teaches skills that can easily be acquired on the job rather than through schooling".

\subsection{Transferability of Skills and Signalling}

If an employee stays in the company where he or she has been trained, in a VET programme or through work expe- 
rience, the chances of remaining employed as well as the wage obtained may be similar for holders of a VET degree and for those having only work experience. However, the situation is different when an employee wants or has to move from one firm to another. In such a situation, the new employer has to estimate the potential employee's productivity in order to determine whether he or she hires the employee, and for which wage. The level of skills required for the position has to be evaluated on the basis of education and work experience. In this case, VET may be seen differently from work experience, because VET includes learning not only firm-specific skills (how to fulfil tasks in the specific context of a firm), but also occupation-specific ones (how to fulfil tasks in different contexts; Müller \& Schweri, 2015). When learning an occupation-and not only gaining experience in a specific position-students following the VET track have the opportunity to acquire skills that are more easily transferable to similar positions in other firms compared to skills gained during years of work experience. VET hence aims at preparing youth to practice an occupation not only in one specific firm, but also in other ones.

If employers have good reason to think a worker is able to immediately apply his or her occupational skills to a new environment, without a long period of adaptation, they are more likely to hire him or her and to pay a higher wage. Therefore, the certificate delivered at the end of VET may open the door to better-paid positions. This last point is explained by the job market signalling theory developed by Spence (1973), who argues that a certificate is a way one party (employers) can access information about another (employees).

\subsection{Differences over the Life-Course}

If dual vocational education is seen as the "gold standard" to enter the labour market and reduce youth unemployment (Hoffman \& Schwartz, 2015), the long-term benefit of this type of education is less clear. Thanks to the work-specific skills learned, vocationally-trained workers are likely to access qualified jobs at a young age, with higher salaries than in non-qualified jobs. However, the potential wage growth of holders of a VET degree may be limited, with small margins for improvement. If at the end of the VET the young workers master the occupation they have learned, the potential of future improvement within the occupation may be modest. This argument is in line with the results of Hanushek et al. (2017) who show that, after the age of 30 , workers with vocational education earn less than workers with general education.

Workers with a lower level of education may have more difficulty entering the labour market because of a (initial) lack of (recognised) skills. However, if they succeed in securing a position and have the opportunity to learn on the job, they may possibly reach a similar skill level as workers with a vocational education certificate. If their productivity is comparable, they are just as likely to get hired and to receive a comparable wage.
This leads us to formulate a first hypothesis:

H1a: Workers with a VET certificate have an advantage in terms of employment and wages over workers with a lower level of education at the entry to the labour market, which decreases over the career as work experience increases.

On the contrary, it is also possible that workers with a VET certificate hold an advantage throughout their entire career. Indeed, research on the life-course has shown that careers often follow a trend of accumulation of advantages and disadvantages (DiPrete \& Eirich, 2006), which would lead us to expect more successful careers after a good start than after a more difficult one. Being more likely to find a good position, workers with a vocational education certificate may succeed in keeping their position or moving to another one, because their good start sends a positive signal to employers. Conversely, workers without an upper-secondary degree are more likely to experience spells of unemployment at the beginning of their career, which may lead to a higher risk of unemployment throughout their entire career-leaving a scarring effect (Gangl, 2006). Furthermore, the signal of having achieved an upper-secondary degree may be rewarded by employers not only at the beginning of the career, but also later on in one's career.

This argument leads us to the opposite hypothesis:

H1b: Workers with a VET certificate benefit from a better start in their career and have a steadily increasing advantage in terms of employment and wages over workers with a lower level of education during their career.

\subsection{Institutional Differences of VET: Specificity and Standardisation}

Up to now, our discussion of education and the labour market was presented as if VET systems were homogeneous across national contexts. This is not the case. Several aspects have been highlighted in the literature to describe the institutional differences of the VET systems, notably the level of specificity or institutional linkage, the standardisation of the content and final exams as well as the degree of stratification or differentiation (Bol \& Van de Werfhorst, 2013; Breen, 2005; Grønning, Kriesi, \& Sacchi, 2018; Levels, van der Velden, \& Di Stasio, 2014; Wolbers, 2003). We focus in this article on two dimensions: specificity and standardisation.

Schematically, vocational education can be organised in two different ways: in the firm-based dual system (apprenticeship) and in vocational schools. The dual system, where students share their time between the workplace and school, is well-established in a group of countries including Austria, Denmark, Germany, the Netherlands, and Switzerland (Wolter \& Ryan, 2011) and is based on the principle of occupation-specific skills (Müller \& 
Schweri, 2015). Working in a firm as part of the training gives a specific orientation to young workers, while vocational programmes spent at school tend to focus on a wider range of occupational skills (Bol \& Van de Werfhorst, 2013, p. 5). In a firm, apprentices solve "real tasks", providing them not only with specific but also work-relevant skills (Breen, 2005). Vocational specificity of the educational system of a given country has thus been measured by the prevalence of the dual system in that country (Bol \& Van de Werfhorst, 2013, p. 13). Recent findings suggest that the level of specificity impacts the situation on the labour market of VET graduates: Similar to Wolbers (2007), De Lange, Gesthuizen and Wolbers (2014) find that VET graduates in more vocationally-specific educational systems benefit from easier integration into the labour market.

Another important difference between the dual system and school-based vocational programmes concerns the role, in the former, of the employer who hires the apprentice and follows his or her progress during the apprenticeship. Due to a first experience with an employer, the signalling of an apprenticeship is positive in terms of an employee's skills (OECD, 2010, p. 105). It provides other employers with a better signal about workers' skill levels and potential productivity (Breen, 2005, p. 126). As a consequence, the signal of a VET degree may be strongest in a country with a highly specific VET system.

The role of employers is not restricted to hiring and supervising apprentices, but also involves defining the content of the apprenticeship and the competences required to obtain a given certificate. Employers' involvement is crucial in connecting apprenticeships, and vocational education more generally, to the needs of the labour market (OECD, 2010, p. 139). Defining skills that have to be learned by every apprentice to earn a VET diploma is the process of standardisation defined as "the degree to which the quality of education meets the same standards nationwide" (Allmendinger, 1989, p. 233).

A standardised system not only benefits workers, who are able to leave the firm where they undertook the apprenticeship without expecting a strong reduction of their productivity and thus their wage, but is also advantageous to firms at the moment of hiring (Allmendinger, 1989, p. 239). Thanks to a standardised system, employers can hire young workers knowing they have a basic level of occupational skills in their field, as well as a certain professionalism and capacity to learn.

In a system where every firm has to teach a set of abilities that are useful not only to the firm itself but to all the firms of the sector, workers are ready to move to a different firm at the end of their training (OECD, 2010 , p. 22). To increase the signalling of a given skill set, a national diploma or certificate is given at the end of the vocational education to workers able to demonstrate all the required skills. A nationally standardised vocational degree recognised by employers helps in particular for labour market entry (Müller \& Gangl, 2003).
Consequently, the more firms recognise the diploma or certificate, the more useful the diploma is for workers.

\subsection{Comparison of Two National Contexts}

We analyse the evolution of wages and employment over the life-course for two countries with different VET systems: the United Kingdom and Switzerland. These two countries share a tradition of vocational education, and of apprenticeships more precisely (Cörvers et al., 2011), and a sizeable part of their population holds such a diploma; in the United Kingdom, $21 \%$ of adults between 25 and 64 had vocational education at the uppersecondary level as their highest level of education compared to 39\% in Switzerland in 2014 (OECD, 2015, p. 45). While the share of holders of a VET degree is larger in Switzerland, this aspect is not the only difference between the two countries. We focus on two aspects: the prevalence of the dual programmes and the standardisation of the VET programmes.

After the end of compulsory school, students in both countries can follow different options within the vocational track. In Switzerland, a large majority of the vocational programmes are taught in the dual form $(90 \%$ for the year 2005, own calculation from OECD, 2007, p. 277). Those programmes combine school- and work-based education and are also called apprenticeships. While the current rate of youth enrolled in an apprenticeship is low today in the United Kingdom (Bol \& Van de Werfhorst, 2013; Brunello \& Rocco, 2015; Cörvers et al., 2011), it was larger in the seventies and eighties, the period of observation for this article, with around half of holders of a vocational upper-secondary level being an apprenticeship (own calculation; see Section 3, on data, for more details).

A second important institutional difference between the two countries lies in the level of standardisation, or unification, of the VET system. On the one hand, Switzerland benefits from a nationally harmonised system, with national certificates that give official recognition to VET skills acquired at the upper-secondary level for over 250 occupations (OECD, 2009). Standardised final exams need to be passed in order to obtain the Federal VET Diplomas. In contrast, there is no unified structure of VET in the United Kingdom (Cörvers et al., 2011) and the system is described as "opaque" even by experts (Ryan, 2001). For the period observed in our analysis, the main VET programmes are trade apprenticeships, National Vocational Qualification at level 3 (NVQ3), Business and Technology Education Council (BTEC), and City and Guilds advanced craft (Jenkins, Greenwood, \& Vignoles, 2007).

The signalling of VET as well as the transferability of skills for VET graduates are hypothesised to be stronger in contexts of high standardisation of VET diplomas, in comparison with holders of lower education (Bol \& Van de Werfhorst, 2013). In less standardised systems, it is more difficult for employers to assess the skills poten- 
tial employees possess given their diploma, and the signalling of the diploma is thus weaker. Similarly, skills transfer more easily in a more standardised context, because the skills learned during the training meet the expectation of the new employer.

We expect employability and wages to be higher if the signal of a diploma is stronger (standardisation), as well as if the connection between the vocational programmes and the labour-market needs is tighter (specificity). Hence, given the institutional differences between the United Kingdom and Switzerland, we formulate a second hypothesis:

$\mathrm{H} 2$ : The employment and earnings advantage of workers with vocational education over workers with a lower level of education is larger in Switzerland than in the United Kingdom, thanks to the higher specificity and standardisation of Switzerland's VET system.

\section{Data and Method}

\subsection{Data}

Our analyses are based on the UK Labour Force Survey 1993-2014 and the Swiss Labour Force Survey 1991-2014, pooling the available rounds. This allows us to work on large datasets considering a period of more than twenty years. To restrict our analysis to a more homogeneous group, we focus on one cohort. To be able to observe workers from 25 to 60, we follow the cohort 1954-1968 over the 22 (UK Labour Force Survey) and 24 (Swiss Labour Force Survey) rounds. Because the same individual is not observed several times (we do not take the mini-panel structure of the Swiss Labour Force Survey into account), we use a pseudo-cohort design. This means that we pool information from different individuals born in a similar period to "compose" an average career of our groups of interest from the age of 25 to the age of 60. According to Deaton (1985), pseudo- panels-and pseudo-cohorts-have some advantages over "real" panels: a lower attrition rate, better representativeness (due to a larger number of observed individuals for a given number of observations) and a lower impact of measurement errors. After selecting the two educational groups of interest for this article (uppersecondary vocational education and compulsory education and lower born between 1954 and 1968), the sample sizes are 214,826 for the United Kingdom and 72,945 for Switzerland.

The structure of the population in terms of educational level is not exactly the same in Switzerland and the United Kingdom, as presented in Table 1. The main difference between the United Kingdom and Switzerland is the importance of the upper- and intermediate secondary education categories (upper-secondary: $20 \%$ UK vs $49 \% \mathrm{CH}$; intermediate secondary $22 \%$ UK vs $4 \% \mathrm{CH}$; for more details about educational levels in the two countries see Table A1 in the Appendix). If we do not distinguish between upper-secondary and intermediate secondary, the rate of secondary education is not too different in the two countries ( $42 \%$ in the United Kingdom and $53 \%$ in Switzerland), but the share of vocational education is more than two times lower in the United Kingdom (44\% against $17 \%)$. However, the general structure is similar, with around $30 \%$ of the population being highly educated (tertiary level of education) and around 15 to $20 \%$ having lower education (compulsory or lower).

This article focuses on vocational education at the upper-secondary level, the main category for vocational education in the two countries. In the United Kingdom, the category "vocational education at the upper-secondary level" is split into several programmes: trade apprenticeships represent slightly more than half the category (55\%), the NVQ3 represents $15 \%$, the BTEC and similar represent $14 \%$, and the City and Guilds advanced craft represents $14 \%$. In Switzerland, the firmbased apprenticeship is dominant with $86 \%$ of the category. The remaining $14 \%$ have attended a full-time

Table 1. Distribution of the population aged 25 to 60 across education in the United Kingdom and in Switzerland, cohort born 1954-1968.

\begin{tabular}{|c|c|c|}
\hline & United Kingdom & Switzerland \\
\hline Tertiary & $27 \%$ & $31 \%$ \\
\hline Upper-secondary & $20 \%$ & $49 \%$ \\
\hline general & $7 \%$ & $7 \%$ \\
\hline vocational & $13 \%$ & $42 \%$ \\
\hline Intermediate secondary & $22 \%$ & $4 \%$ \\
\hline general & $19 \%$ & $2 \%$ \\
\hline vocational & $4 \%$ & $2 \%$ \\
\hline Compulsory or lower & $22 \%$ & $15 \%$ \\
\hline Other/missing & $8 \%$ & $1 \%$ \\
\hline Total & $100 \%$ & $100 \%$ \\
\hline
\end{tabular}

Source: UK Labour Force Survey 1993-2014 ( $\mathrm{N}=614,293)$ and Swiss Labour Force Survey 1991-2014 ( $\mathrm{N}=126,859)$, own calculation. Notes: Unweighted results. After verification, the proportion of each group is similar to the weighted ones. Details of each category in Table A1 in the Appendix. 
school vocational programme, which leads to the same certificate as the apprenticeship (Federal VET Diplomas).

The group of comparison for this article is holders of compulsory school level or lower education (called lower). It includes persons with compulsory school as the highest level of education, those who have not completed school, and those who have followed short programmes giving no access to the intermediate secondary level of education. In the United Kingdom, 87\% of this group have attended compulsory school or less, and $13 \%$ have completed a short training, such as city and guilds part 1 , which is lower than secondary education. In Switzerland, the share of persons having attended only compulsory school or lower is $94 \%$, and only $6 \%$ have completed a short training with a lower level of education.

\subsection{Dependent, Independent and Control Variables}

The two dependent variables are employment and wages. Employment is calculated with a binary variable taking the value of 1 if the person works at least 8 hours per week, and 0 if the person works less than 8 hours per week or not at all (this last category includes housework, education, retirement, illness, etc.; additional results considering people working at least 20 hours per week are shown in the Appendix). Income is measured as the hourly wage, calculated by dividing the gross annual work income by the number of hours worked (number per week multiplied by 52; additional results for annual work income are shown in the Appendix). The gross annual work income corresponds to the wages of employees, without self-employed workers and employers who are not available in the UK Labour Force Survey and excluded in the Swiss Labour Force Survey. It is corrected for inflation with December 2010 as the reference. We exclude the top and bottom $1 \%$ of the wage distribution as well as wages of workers working less than 8 hours per week from our models.

The number of observations is lower for wages than for employment. Firstly, the questions about wages are not asked in each wave of the UK Labour Force Survey, and secondly, the wage variables contain a higher rate of missing data, due to the sensitivity of the questions. For this reason, annual wages are available for 34,044 individuals in the UK Labour Force Survey and 49,293 in the Swiss Labour Force Survey. ${ }^{1}$

The two key independent variables are education (vocational education versus lower education) and age (from 25 to 60). As control variables, we use the region (split into 20 regions for the United Kingdom and into the 26 cantons for Switzerland ${ }^{2}$ ) and nationality. All results are presented separately for men and women, since labour market trajectories differ between the two groups.

\subsection{Regression Model and Multivariate Results}

We calculate linear regression models to predict employment and wages by education for men and women. The equation is the same for the two dependent variables and is given as:

$$
\begin{aligned}
& y_{i}=\beta_{1}+\beta_{2} e d u c_{i}+B_{3} a g e_{i}+\beta_{4} a g e_{i}^{2}+\beta_{5} a g e_{i}^{3} \\
& +\beta_{6} a g e_{i}^{4}+\beta_{7} e d u c_{i} \times a e_{i}+\beta_{8} e d u c_{i} \times a g e_{i}^{2} \\
& +\beta_{g} e d u c_{i} \times a g e_{i}^{3}+\beta_{10} e d u c_{i} \times a g e_{i}^{4}+\beta_{11} W_{i}+\varepsilon_{i}
\end{aligned}
$$

Where $y_{i}$ is first a binary variable $(0 / 1)$ measuring if the person works or not and secondly the natural logarithm of hourly wage for an individual at a given moment, $W_{i}$ is a vector of controls composed of the region and nationality, and $\varepsilon_{i}$ is the error term. The two key independent variables are educ and age. The binary variable educ indicates whether the person has an upper-secondary vocational level of education, or a lower level of education. The variable age indicates the age of the respondent and is developed into four forms: age, age squared, age cubed and age to the power of four. These variables enable us to account for the non-linear effect of age on the life-cycle curves in employment and wages, in particular for women. We chose to use the term age up to the 4-degrees of polynomials because the coefficient for age $^{4}$ is significant in some of the models shown and the distribution of the predicted values closely mirrors the shape observed in the descriptive results. Each of the forms is then interacted with educ, since we expect a different age curve of the dependent variables depending on the education. We present our results graphically due to the large number of interaction terms.

\section{Employment Trajectories in the United Kingdom and in Switzerland}

The four graphs of Figure 1 present descriptive evidence for the employment rate over the life-course in the United Kingdom (left) and in Switzerland (right) for the two groups of interest: holders of an uppersecondary vocational level of education (vocational) and holders of a compulsory school level or lower (lower), for men and women. We present the results for wages in the appendix.

We observe three important aspects about employment: (1) In Switzerland and the United Kingdom, for both men and women, the employment rate of holders of vocational education is higher than the employment rate of holders of lower education; (2) this difference is greater in the United Kingdom than in Switzerland; (3) this difference seems stable during the career in the United Kingdom, but tends to increase across the career for Swiss men, and women after the age of 35.

\footnotetext{
${ }^{1}$ Due to the availability of this information in the Swiss Labour Force Survey, we have imputed part of the missing wage data with a regression model containing age, year, canton, type of municipality, residential permit and nationality, occupation studied, hours worked, sector of activity, current occupation, and employment status. This allows us to reduce the number of missing earnings from 12,661 ( $12.9 \%$ of the workers) to 670 (less than $0.1 \%$ ). We find similar outcomes with listwise deletion of missing data (results available on request from the author).

2 Regional disparities in the employment structure and job opportunities may impact holders of vocational and lower education differently.
} 

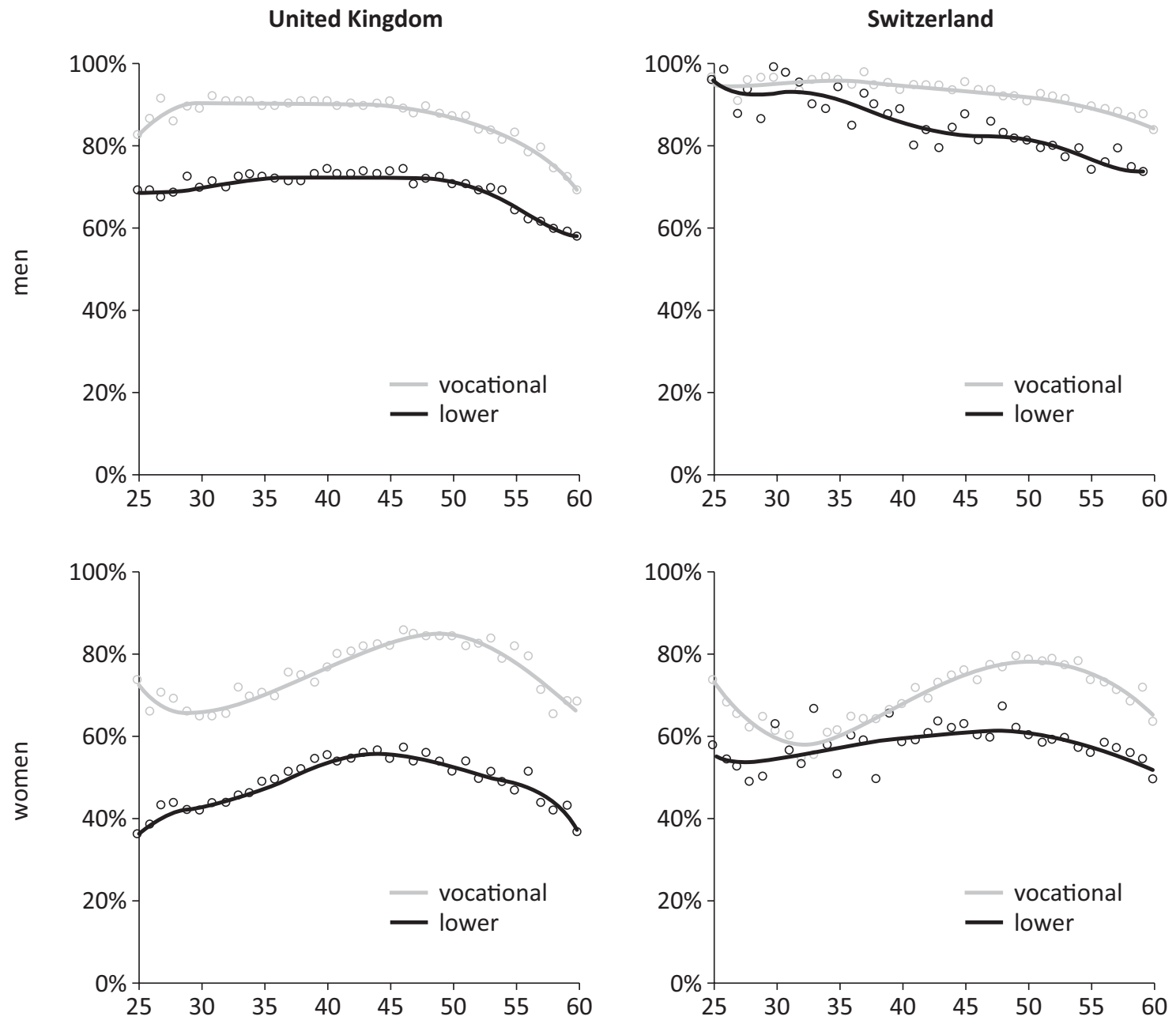

Figure 1. Employment rate (minimum 8 hours per week) for men and women by level of education and age: uppersecondary vocational education (vocational) and compulsory school or lower (lower). Source: UK Labour Force Survey 1993-2014 and Swiss Labour Force Survey 1991-2014, cohort 1954-1968. Note: Black and grey lines represent the polynomial trend line for the respective groups.

In the United Kingdom, the employment rate of holders of vocational education remains high during the entire career, at around $90 \%$ until the age of 50 for men, and between 65 and $85 \%$ for women. In comparison, the employment rate of holders of lower education follows a similar trend but lies 17 (men) to 27 (women) percentage points lower.

In Switzerland, the employment rate is comparable for the two groups of men until the age of 35 (95\%, on average, between 25 and 35 for holders of vocational education and $93 \%$ for holders of lower education). After this period, the employment rate of holders of lower education gradually decreases to $70 \%$ at the age of 60 , while that of holders of vocational education remains almost constant until the age of 60 . This decrease seems to be primarily due to an increasing rate of withdrawal from the labour market ( $6 \%$ between 40 and 49 and $12 \%$ between 50 and 60 ), while unemployment does not increase ( $7 \%$ between 40 and 49 and $5 \%$ between 50 and 60). However, these situations are self-reported and the number of observations per age for each category is limited.

Women in Switzerland with vocational education have a similar employment rate as women with lower education during the first part of their career (around 60\% between 30 and 40 years old). After this period, the employment rate of women with vocational education increases (to almost $80 \%$ around the age of 50 ), while that of women with lower education remains basically flat at $60 \%$. The curve of the "lower" groups-both for men and women-is less stable, especially during the first part of the career. This is partly due to a smaller number of observations in the "lower" group than in the "vocational" one (men: 7,726 vs 25,227; women: 11,533 vs 27,981 ).

In the Appendix, we present two robustness checks: first, in Figure A1, the employment rate for those working at least 20 hours per week (contrary to the minimum of 8 hours presented above) previously; second, in Figures $A 2$ to $A 5$, the employment rate by type of vocational track. ${ }^{3}$

\footnotetext{
${ }^{3}$ UK: apprenticeship, city and guilds advanced, BTEC and NVQ3; $\mathrm{CH}$ : apprenticeship and vocational school. We present these results for the entire available population (and not only the cohort 1954-1968) to obtain a sufficient number of observations.
} 
We provide a more stringent test of our hypotheses by resorting to a multivariate design. We estimate the employment rate and hourly wage of each group at each age, based on linear regression models. We present the coefficients in the Appendix (Table A2 and Table A3). Figure 2 shows the advantage of vocational education, in comparison with lower education, based on these regressions (average marginal effect). Overall, the employment advantage of vocational education is larger in the United Kingdom than in Switzerland, and larger for women than for men in the two countries. More specifically, for men, we can observe an opposite trend in the two countries. The advantage of holders of vocational education is high at the beginning of the career in the United Kingdom (17 percentage points) and decreases slightly during the career to 13 points. In Switzerland, there is no significant advantage of vocational education on employment at the beginning of the career for men. However, the advantage of VET increases during the career and men with vocational education have, on average, an employment rate that is 17 percentage points higher at the age of 60 .

For women, the trend over the career is similar in the two countries with the employment rate difference between the two educational groups taking the shape
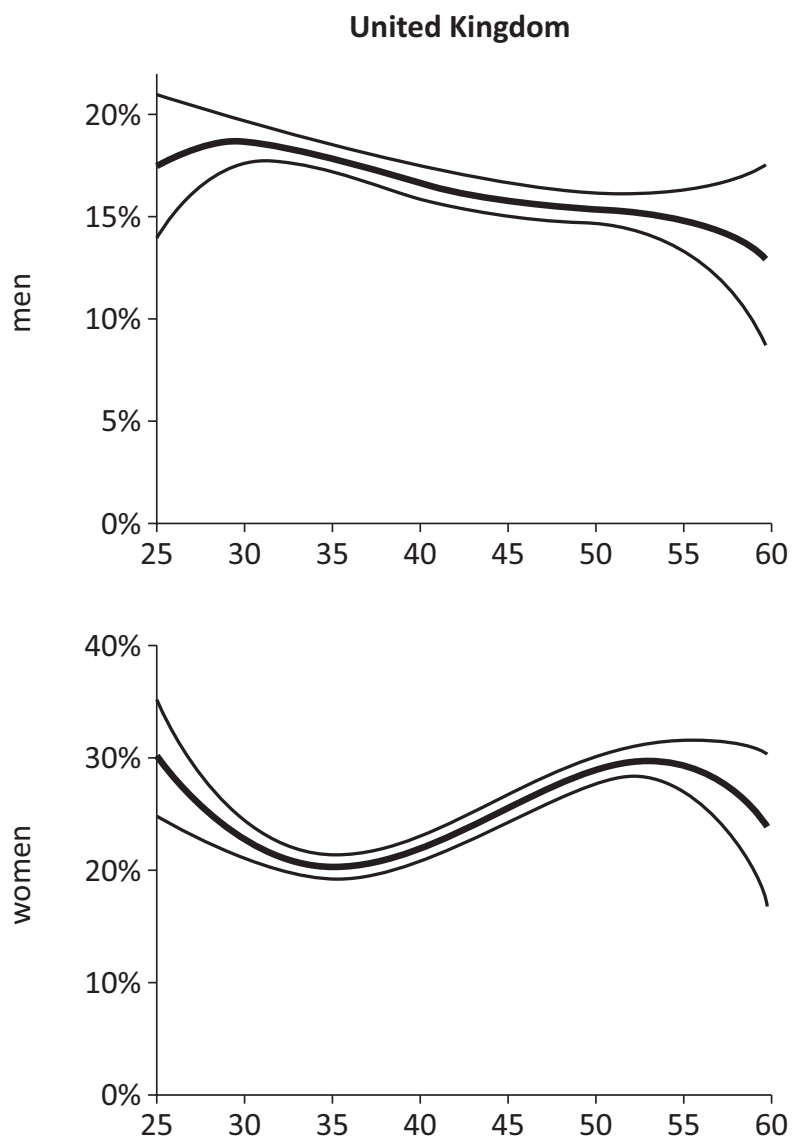

of a horizontal " $\mathrm{S}$ ": the advantage is particularly high at the age of 25 , lower at 35 , high again at 55, and decreases again during the last 5 years observed. However, the level of vocational advantage for women is higher in the United Kingdom-where it fluctuates between 20 and $30 \%$-than in Switzerland-where the evolution is between 5 and $20 \%$.

\section{Wage Trajectories in the United Kingdom and in Switzerland}

Figure 3 presents descriptive results for the hourly wage over the life-course for holders of an upper-secondary vocational level of education and holders of a compulsory school level or lower. Each point represents the median hourly wage for a specific age and the line shows the general trend.

As with the employment rate, the hourly wages of holders of vocational education are higher than those of holders of lower education among men and women, in the United Kingdom and in Switzerland. In the United Kingdom, the mean difference in the hourly wage between holders of lower education and those with uppersecondary vocational education is around $20 \%$ for both men and women. In Switzerland, this difference is slightly
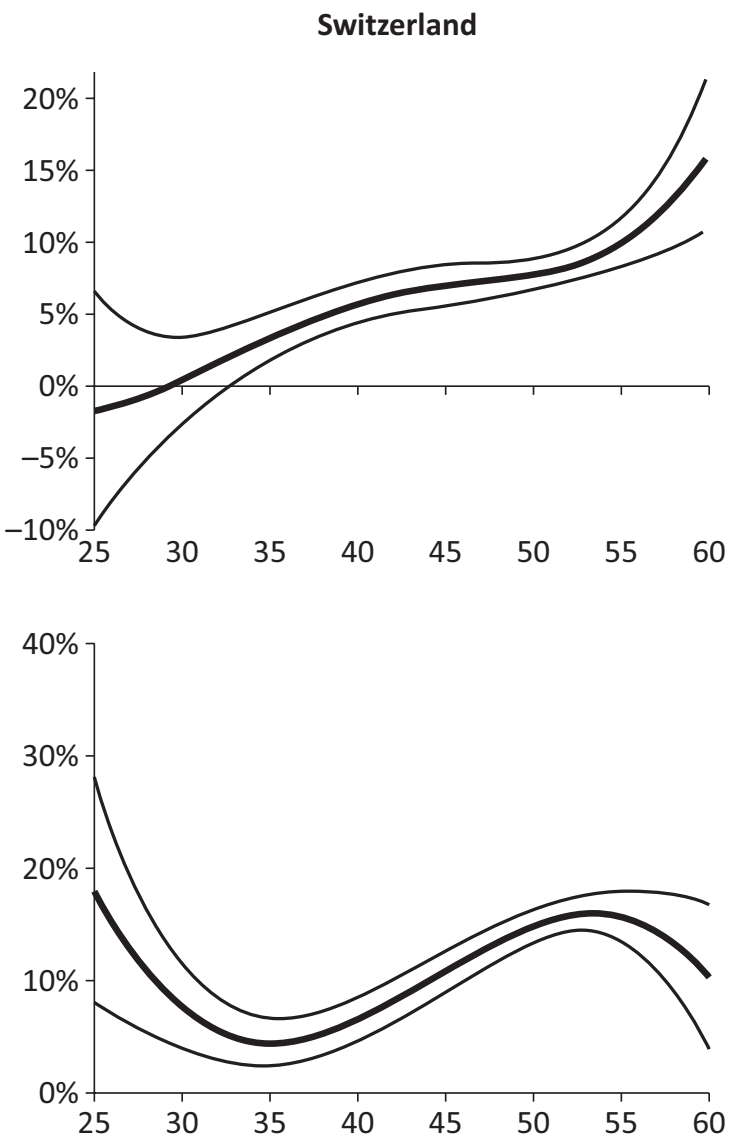

Figure 2. Difference in employment by age for upper-secondary vocational education relative to lower education (average marginal effects). Source: UK Labour Force Survey 1993-2014 and Swiss Labour Force Survey 1991-2014, cohort 1954-1968. Note: Main line stands for average marginal effect; thinner lines stand for $95 \%$ confidence intervals. 

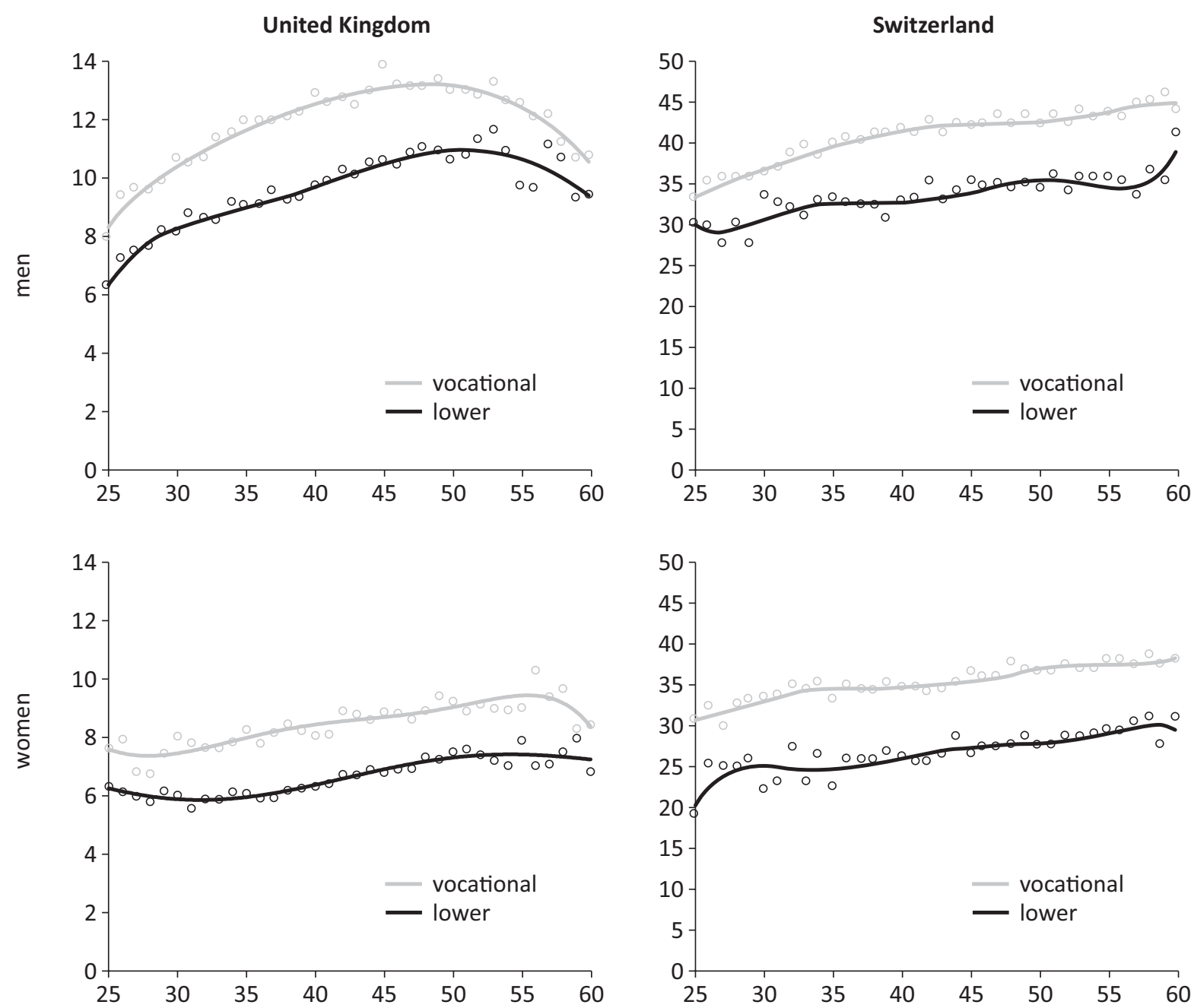

Figure 3. Median hourly wage ( $\mathrm{f} /$ hour for UK, CHF/hour for Switzerland) for men and women by level of education: uppersecondary vocational education (vocational) and compulsory school level or lower (lower). Source: UK Labour Force Survey 1993-2014 and Swiss Labour Force Survey 1991-2014, cohort 1954-1968. Notes: Black and grey lines represent the polynomial trend line for the respective groups. Median hourly wage for the cohort 1954-1968: UK f13, CH CHF48.

smaller for men than in the United Kingdom (18\%) but larger for women (25\%). Regarding the evolution of the difference over the career, the difference between holders of vocational education and holders of lower education remains rather stable for men in the United Kingdom, but tends to be smaller at the end of the career. The hourly wage increases more during the career for men than for women in both countries. ${ }^{4}$

We replicate this analysis with annual median wages (see Figure A6 in the Appendix). This second measure does not take the number of working hours into account. It is then less suitable to measure the "hourly price" (and therefore productivity) but informs us about the money wages available to the respondents. While these two indicators present very similar trends for men, the situation is slightly different for women. Annual median wages by type of vocational track are also presented in the Appendix (see Figures A7 to A10) to take the heterogeneity of the vocational track into account.

We turn again to our multivariate model and show in Figure 4 the predicted advantage of vocational education in hourly wages on lower levels of education, based on linear regression models. On average over the entire career, the wage advantage of vocational education is similar in the two countries: $18 \%$ for men and women in the United Kingdom as well as for women in Switzerland, and $15 \%$ for Swiss men. However, the evolution during the career differs between the two countries.

In the United Kingdom, the advantage of VET increases between 25 and 35, and decreases afterwards. The initial increase is more pronounced for women than for men (respectively from $7 \%$ to $24 \%$ and from $15 \%$ to

\footnotetext{
${ }^{4}$ The decrease of the hourly wage observed for men in the United Kingdom after the age of 50 may be the result of decreasing productivity due to a difficulty to adapt to new technologies for example but may also be due to a measurement effect. There is indeed a "mechanic" tendency of wages to decrease for older workers when observing more than one birth year cohort (here: fifteen). Because of wage growth across time, the salary at a given age of a person born several years later is on average higher than that of a person born earlier (for more details on this effect see Baudelot, 1982).
} 

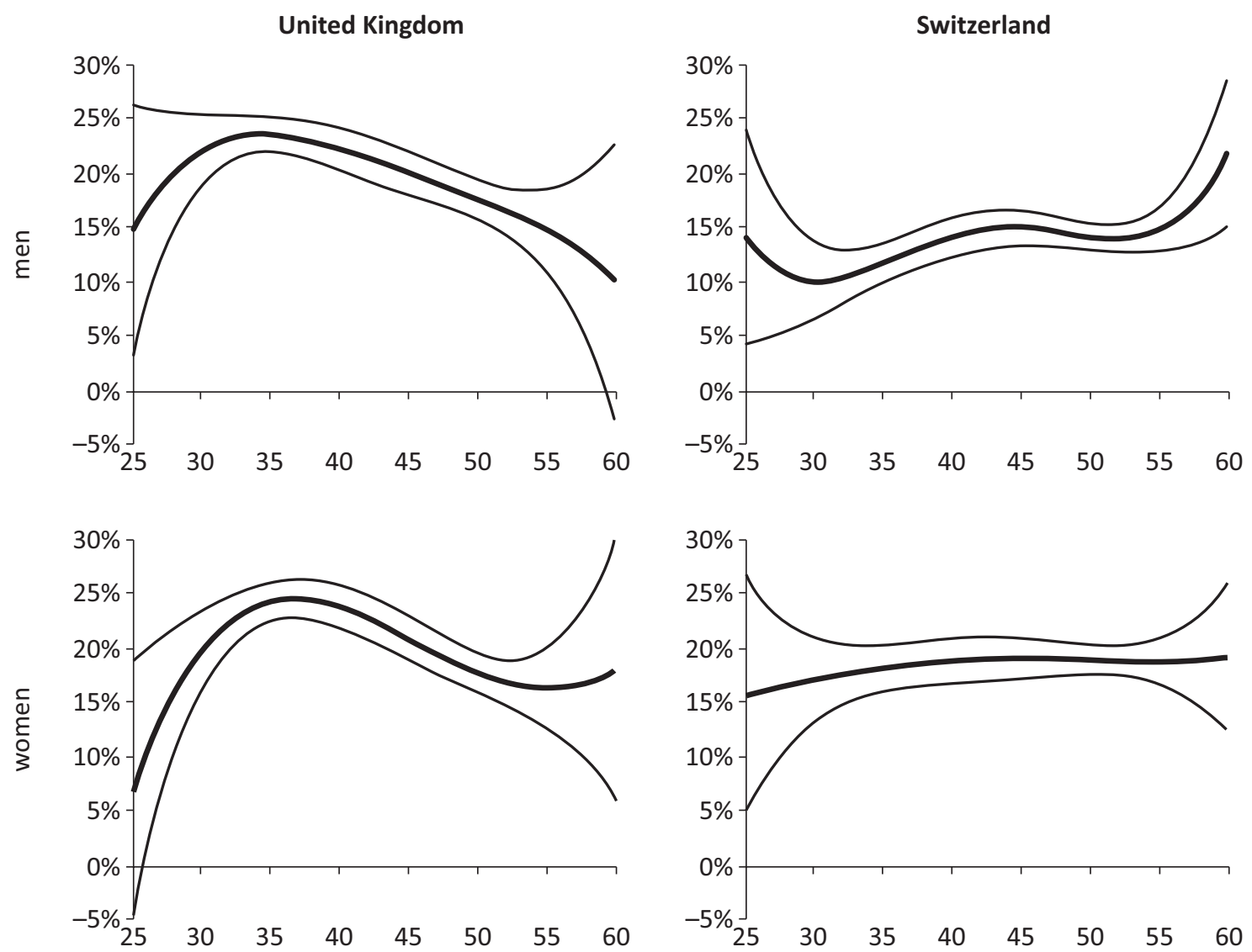

Figure 4. Difference in hourly wage by age for upper-secondary vocational education relative to lower education (average marginal effects). Source: UK Labour Force Survey 1993-2014 and Swiss Labour Force Survey 1991-2014, cohort 1954-1968. Note: Main line stands for average marginal effect, thinner lines stand for $95 \%$ confidence intervals.

24\%). Afterwards, the advantage decreases for men and women to about $15 \%$ at the age of 55 .

In Switzerland, the wage advantage of vocational education is more stable during the career. It is almost constant for women, going from $16 \%$ at the age of 25 to $19 \%$ at 60 . This small increase is not statistically significant since the confidence intervals around the value at the age of 25 and the one at the age of 60 overlap. For men, the increase between the ages of $30(10 \%)$ and 60 $(23 \%)$ is statistically significant.

The advantage of vocational education on annual wages is presented in the Appendix (Figure A11). While the observation of this measure leads us to similar conclusions as the observation of the hourly wage, we can observe one interesting difference. Men and women with lower education seem to not only receive a lower hourly wage in both countries, but also tend to work fewer hours per week. Therefore, the advantage of vocationally-trained men becomes larger when we look at hourly compared to annual wages.

\section{Discussion}

The analyses of employment rates and wages over the career in the United Kingdom and Switzerland for holders of vocational education in comparison to holders of lower education show us three main results: (1) a constant advantage of holders of vocational education over those with lower education in the two countries, for both men and women, and during the entire careerwith rare exceptions where the difference is not statistically significant; (1) for employment, a larger advantage of VET in the United Kingdom than in Switzerland and for women than for men; (3) for hourly wage, a similar advantage over the career for men and women in the two countries.

We do not have a simple answer to our first hypothesis. Results for men and women in the United Kingdom tend to confirm hypothesis $\mathrm{H} 1 \mathrm{a}$, which expected a decreasing advantage of vocational education over the career. However, this is only valid after the age of 35 . Afterwards, holders of lower education may have acquired some work experience, which helps them to catch up with VET graduates, which is in line with expectations derived from the human capital theory. On the contrary, results for Swiss men confirm hypothesis $\mathrm{H} 1 \mathrm{~b}$, showing an increase in the vocational advantage over the career, a finding that instead corresponds to the cumulative (disladvantages theory (DiPrete \& Eirich, 2006). For women in Switzerland, we find none of the predicted trend, but have a stable effect on wages and a horizontal " $\mathrm{S}$ " curve for employment. This shows the importance of account- 
ing for the involvement of a large share of women in household tasks and family life in predicting the evolution of labour market careers.

Contrary to hypothesis $\mathrm{H} 2$, which expected a larger advantage of vocational education in Switzerland than in the United Kingdom, we observe the opposite, a larger advantage in the United Kingdom, especially in terms of employment. The larger difference in employment rates in the United Kingdom may be due to a stronger selection process at the upper-secondary vocational education level in the United Kingdom than in Switzerland. The proportion of the population with this level of education is indeed substantially larger in Switzerland than in the United Kingdom. However, because the difference in terms of wage is similar in the two countries, we could also interpret this result as showing an overall stronger labour demand in Switzerland for workers, even without qualification. In a context of almost full employment, as is the case in Switzerland, many employers may have no other choice than to appoint unqualified workers. During the observed period (1991-2014), the unemployment rate is indeed higher in the United Kingdom (between 5 and 10\%) than in Switzerland (between 2 and 5\%).

The difference in trends over the career for workers in the United Kingdom and in Switzerland (mostly men in the latter case) suggests that different mechanisms are at work in the two countries. This may be linked to the difference in terms of specificity and standardisation of the VET system: In a highly standardised and specific VET system, such as Switzerland, the possibility for holders of lower education to catch up with holders of VET may be more limited than in the United Kingdom, as our results suggest. However, since we do not know the respondents' amount of work experience, we can only use age as a proxy. Hence, these results have to be interpreted cautiously. Furthermore, we observe those trends for men, but not for women. For the latter, the advantage of VET on employment rate takes a horizontal " $\mathrm{S}$ " shape, which may be more closely linked to family tasks than to demand on the labour market.

\section{Conclusion}

Our results clearly highlight the better position on the labour market for holders of vocational education than holders of lower education, in terms of employment prospects and wages over the entire career. Vocational education appears not only key to enter the labour market, but also to shield against non-employment and very low wages. If women's careers are more affected by family events than men's, we nevertheless observe an advantage of vocational education for both men and women.

The effort of strengthening vocational tracks in the educational system appears as clearly relevant, to not only avoid educational drop-outs but also to offer better opportunities in the labour market to youth less interested in, or having more difficulties with, general education. This conclusion can be drawn for both a na- tionally standardised and very specific system, such as Switzerland, as well as a less standardised and less specific context, such as the United Kingdom.

However, it is important to keep in mind the limitations of this article. First of all, our results do not derive from a causal design, which means this article is unable to prove that the difference between the two groups comes from the level of education. It has indeed been shown in the literature that (self-)selection in educational tracks not only depends on ability, but also on other factors such as social origin (Erikson \& Rudolphi, 2009; Goldthorpe, 1996). The population association presented in this article does not take this selection bias into account, due to the lack of relevant information in the datasets. Presenting a detailed, and careerlong, description of the labour market situation of the two groups appears nevertheless interesting to us.

Finally, it is also important to remember that we present respondents who entered the labour market 30 to 45 years ago. In a context of globalisation and digitalisation, it is difficult to predict how the careers of youth entering the labour market nowadays will evolve. However, the high employment rates of our study's cohort today-who are now in their fifties and early sixties-strongly suggest that the demand for vocationally-trained workers will not only persist, but also continue to exceed that for non-qualified workers. The challenge for governments may then be the constant modernisation of vocational systems in order to face the increasing importance of information technology in most vocational domains.

\section{Acknowledgments}

This article was written within the Swiss National Centre of Competence in Research "LIVES-Overcoming Vulnerability: Life Course Perspectives" project, funded by the Swiss National Science Foundation. I gratefully acknowledge my supervisor, Daniel Oesch, for his help throughout the process of this article. I also want to thank André Berchtold, Thijs Bol, Ben Jann, Fabienne Liechti, Roman Liesch and Patrick McDonald for their useful comments and help, as well as the seminar participants in Milano (ECSR), Zollikofen (GOVPET graduate workshop) and Lausanne (Labour Market Colloquium IDHEAP). Finally, I want to thank the editors, Irene Kriesi and Jürg Schweri, and three anonymous reviewers.

\section{Conflict of Interests}

The authors declare no conflict of interests.

\section{References}

Allmendinger, J. (1989). Educational systems and labor market outcomes. European Sociological Review, 5(3), 231-250.

Arum, R., \& Shavit, Y. (1995). Secondary vocational edu- 
cation and the transition from school to work. Sociology of Education, 68(3), 187.

Baudelot, C. (1982). L'évolution des salaires: Une approche nouvelle [The evolution of wages: A new approach]. Economie et statistique, 149(1), 3-11. https://doi.org/10.3406/estat.1982.4680

Becker, G. S. (1962). Investment in human capital: A theoretical analysis. Journal of Political Economy, 70(5), 9-49.

Bol, T., \& Van de Werfhorst, H. G. (2013). The measurement of tracking, vocational orientation, and standardization of educational systems: A comparative approach (Discussion Paper 81). Amsterdam: GINI Growing Inequalities' Impacts.

Boud, D., \& Garrick, J. (Eds.). (1999). Understanding learning at work. London: Routledge.

Breen, R. (2005). Explaining cross-national variation in youth unemployment: Market and institutional factors. European Sociological Review, 21(2), 125-134.

Brunello, G., \& Rocco, L. (2015). The labour market effects of academic and vocational education over the life cycle: Evidence from two UK cohorts (Working Paper 9275). Bonn: IZA Institute of Labor Economics. Retrieved from https://www.econstor.eu/ handle/10419/114150

Cörvers, F., Heijke, H., Kriechel, B., \& Pfeifer, H. (2011). High and steady or low and rising? Life-cycle earnings patterns in vocational and general education (ROA Research Memorandum 007). Maastricht: Maastricht University, Research Centre for Education and the Labour Market.

De Lange, M., Gesthuizen, M., \& Wolbers, M. H. (2014). Youth labour market integration across Europe: The impact of cyclical, structural, and institutional characteristics. European Societies, 16(2), 194-212.

Deaton, A. (1985). Panel data from time series of crosssections. Journal of Econometrics, 30(1/2), 109-126.

DiPrete, T. A., \& Eirich, G. M. (2006). Cumulative advantage as a mechanism for inequality: A review of theoretical and empirical developments. Annual Review of Sociology, 32, 271-297.

Erikson, R., \& Rudolphi, F. (2009). Change in social selection to upper secondary school: Primary and secondary effects in Sweden. European Sociological Review, 26(3), 291-305.

Forster, A., Bol, T., \& van de Werfhorst, H. (2016). Vocational education and employment over the life cycle. Sociological Science, 3, 473-494. https://doi.org/ 10.15195/v3.a21

Gangl, M. (2006). Scar effects of unemployment: An assessment of institutional complementarities. American Sociological Review, 71(6), 986-1013.

Goldthorpe, J. H. (1996). Class analysis and the reorientation of class theory: The case of persisting differentials in educational attainment. The British Journal of Sociology, 47(3), 481.

Grønning, M., Kriesi, I., \& Sacchi, S. (2018). Institutional dimensions of Swiss VET: Measures of stan- dardization, differentiation and vocational specificity in Swiss upper secondary vocational education and training (Working Paper). Zollikofen: Swiss Federal Institute for Vocational Education and Training (SFIVET).

Hanushek, E. A., Schwerdt, G., Woessmann, L., \& Zhang, L. (2017). General education, vocational education, and labor-market outcomes over the life-cycle. Journal of Human Resources, 52(1), 48-87.

Hoffman, N., \& Schwartz, R. (2015). Gold standard: The Swiss vocational education and training system. Washington, DC: National Center on Education and the Economy.

Jenkins, A., Greenwood, C., \& Vignoles, A. (2007). The returns to qualifications in England: Updating the evidence base on level 2 and level 3 vocational qualifications. London: Centre for the Economics of Education, London School of Economics and Political Science.

Levels, M., van der Velden, R., \& Di Stasio, V. (2014). From school to fitting work: How education-to-job matching of European school leavers is related to educational system characteristics. Acta Sociologica, 57(4), 341-361.

Müller, W., \& Gangl, M. (Eds.). (2003). Transitions from education to work in Europe: The integration of youth into EU labour markets. Oxford: Oxford University Press.

Müller, B., \& Schweri, J. (2015). How specific is apprenticeship training? Evidence from inter-firm and occupational mobility after graduation. Oxford Economic Papers, 67(4), 1057-1077.

OECD. (2007). Education at a glance 2007: OECD indicators. Paris: OECD Publishing.

OECD. (2009). Learning for jobs: OECD reviews of vocational education and training-England and Wales. Paris: OECD Publishing.

OECD. (2010). Learning for jobs: synthesis report of the OECD reviews of vocational education and training. Paris: OECD Publishing.

OECD. (2015). Education at a glance 2015: OECD indicators. Paris: OECD Publishing.

Ryan, P. (2001). The school-to-work transition: A crossnational perspective. Journal of Economic Literature, 39(1), 34-92.

Shavit, Y., \& Müller, W. (Eds.). (1998). From school to work: A comparative study of educational qualifications and occupational destinations. Oxford: Clarendon Press.

Shavit, Y., \& Müller, W. (2000a). Vocational secondary education. European Societies, 2(1), 29-50.

Shavit, Y., \& Müller, W. (2000b). Vocational secondary education, tracking, and social stratification. In M. T. Hallinan (Ed.), Handbook of the sociology of education (pp. 437-452). New York, NY: Springer US.

Spence, M. (1973). Job Market Signaling. The Quarterly Journal of Economics, 87(3), 355-374.

Wolbers, M. H. J. (2003). Job mismatches and their labour-market effects among school-leavers in Eu- 
rope. European Sociological Review, 19(3), 249-266.

Wolbers, M. H. (2007). Patterns of labour market entry:

A comparative perspective on school-to-work transitions in 11 European countries. Acta Sociologica, 50(3), 189-210.

Wolter, S. C., \& Ryan, P. (2011). Apprenticeship. In E. A. Hanushek, S. J. Machin, L. Woessmann (Eds.), Hand- book of the economics of education (pp. 521-576). New York, NY: Elsevier.

Wolter, S. C., Cattaneo, M. A., Denzler, A., Diem, A., Grossenbacher, S., \& Hof, S. (2014). Swiss education report 2014. Aarau: Swiss Coordination Centre for Research in Education (SKBF/CSRE).

\section{About the Author}

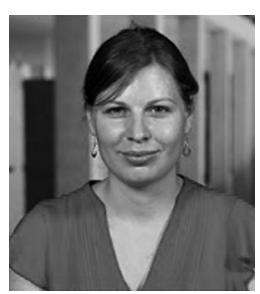

Maïlys Korber holds a PhD in Social Sciences from the University of Lausanne, in the field of labour market sociology. This article is part of her dissertation The Labour Market Returns to Vocational Education over the Life Course (available online), which she defended in February 2019. She is an associate member of the Life Course and Inequality Research Centre and the Swiss National Centre of Competence in Research LIVES. 


\section{Appendix}

\section{Figures}
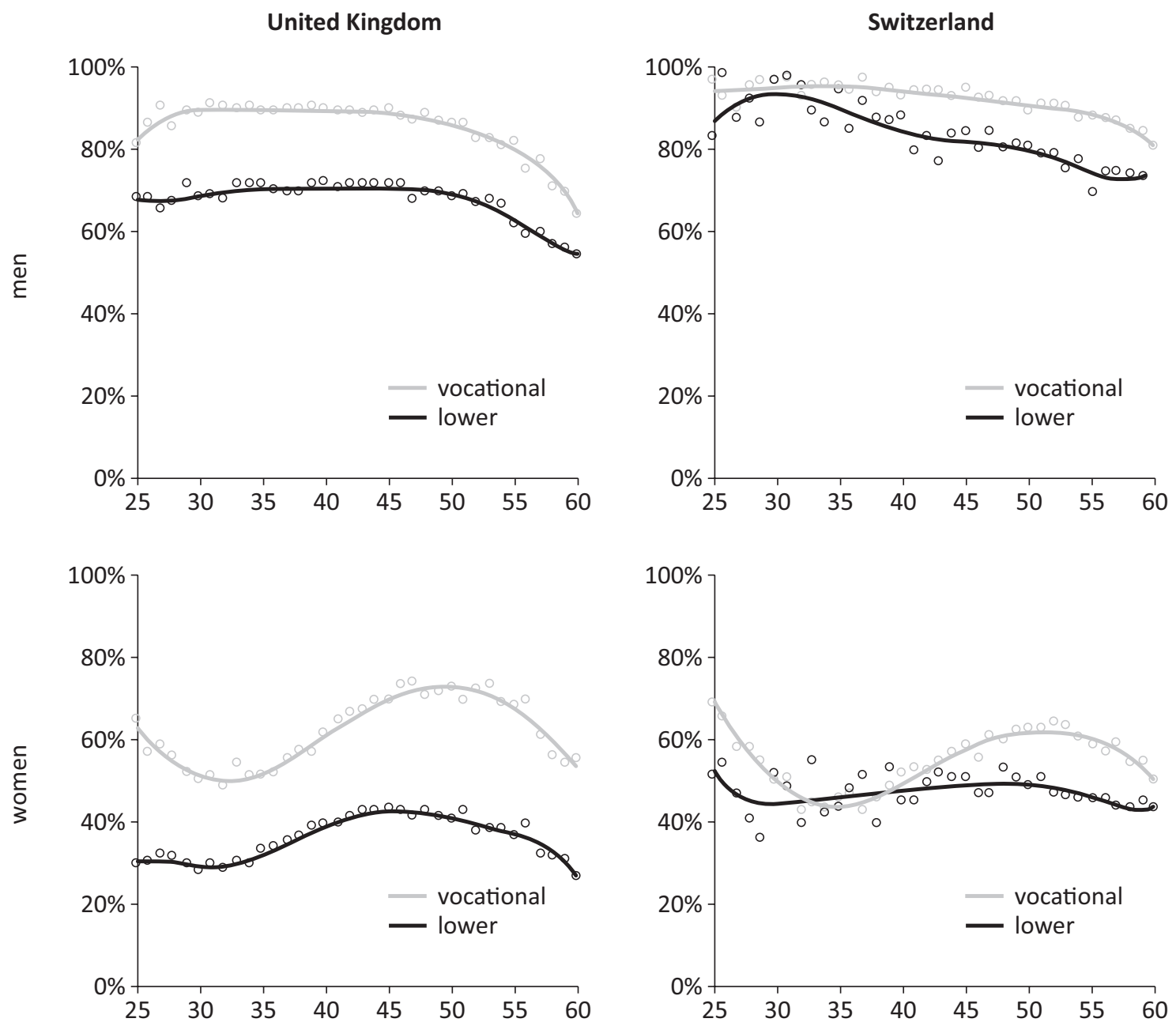

Figure A1. Employment rate (minimum 20 hours per week) for men and women by level of education: upper-secondary vocational education (vocational) and compulsory school level or lower (lower). Source: UK Labour Force Survey 1993-2014 and Swiss Labour Force Survey 1991-2014, cohort 1954-1968. 


\section{COGITATIO}

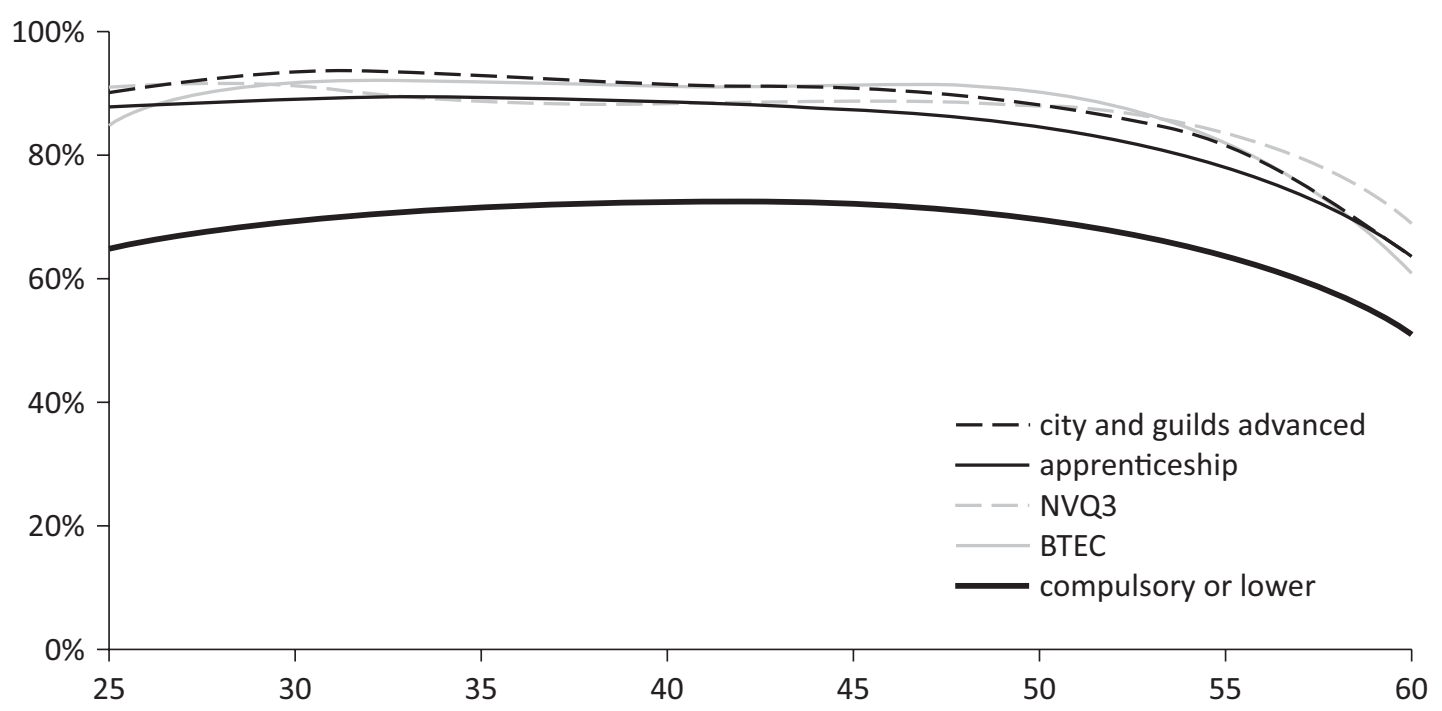

Figure A2. Employment rate (minimun 8 hours per week) by type of upper-secondary vocational education. Men-United Kingdom. Source: UK Labour Force Survey 1993-2014.

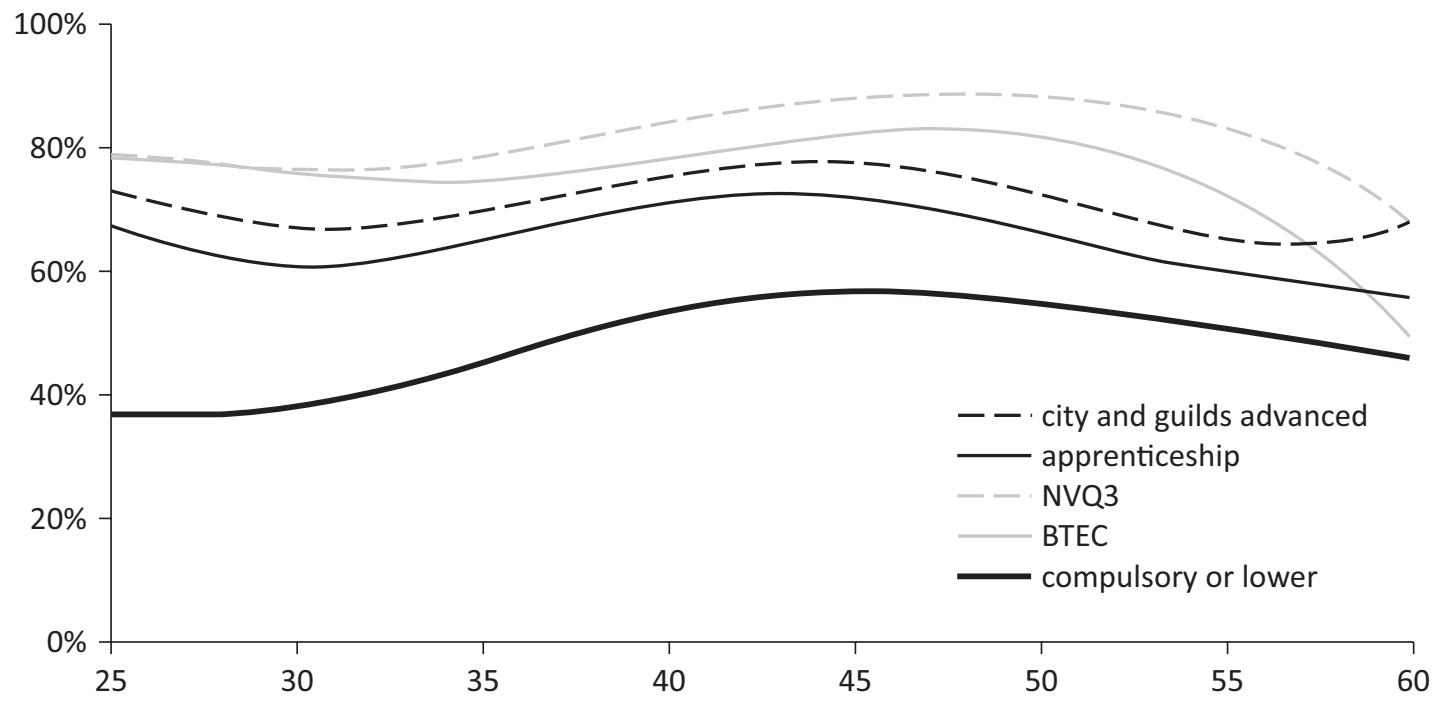

Figure A3. Employment rate (minimun 8 hours per week) by type of upper-secondary vocational education. WomenUnited Kingdom. Source: UK Labour Force Survey 1993-2014. 


\section{COGITATIO}

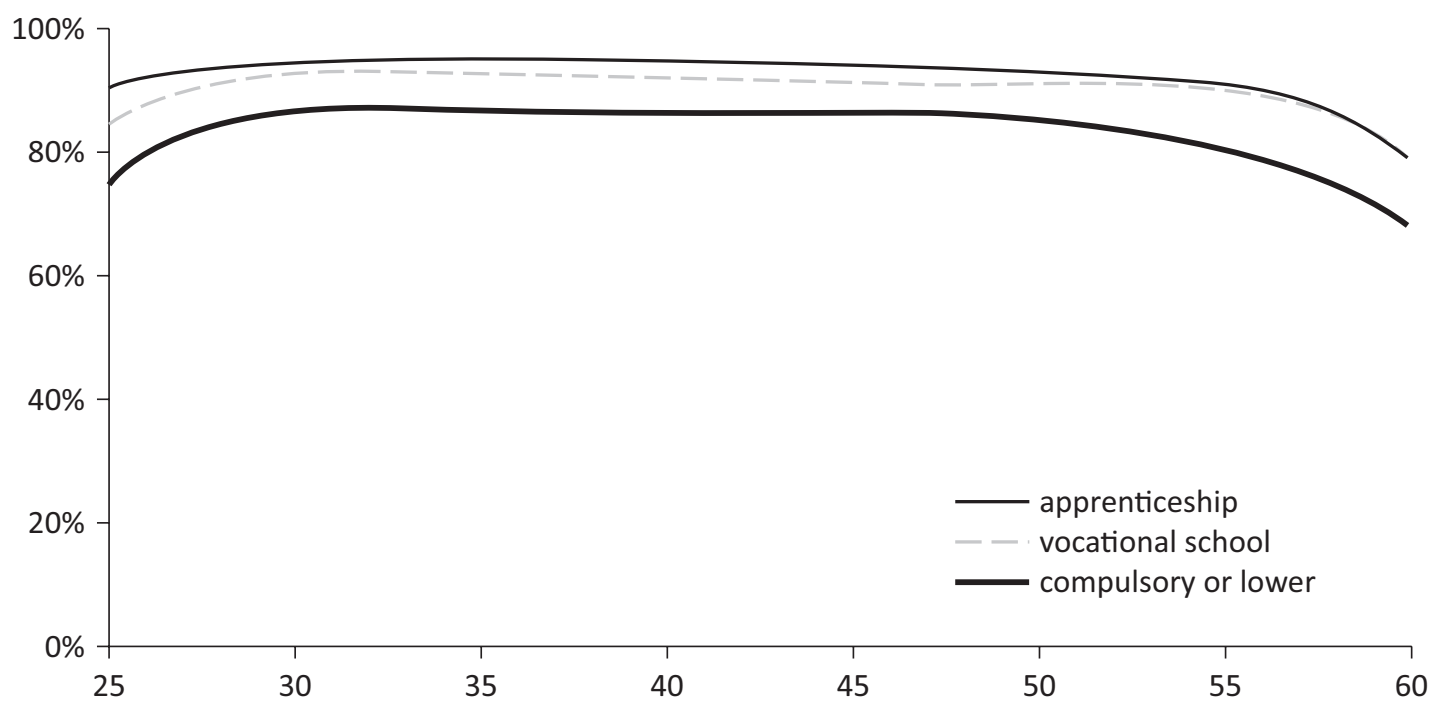

Figure A4. Employment rate (minimun 8 hours per week) by type of upper-secondary vocational education. MenSwitzerland. Source: Swiss Labour Force Survey 1991-2014.

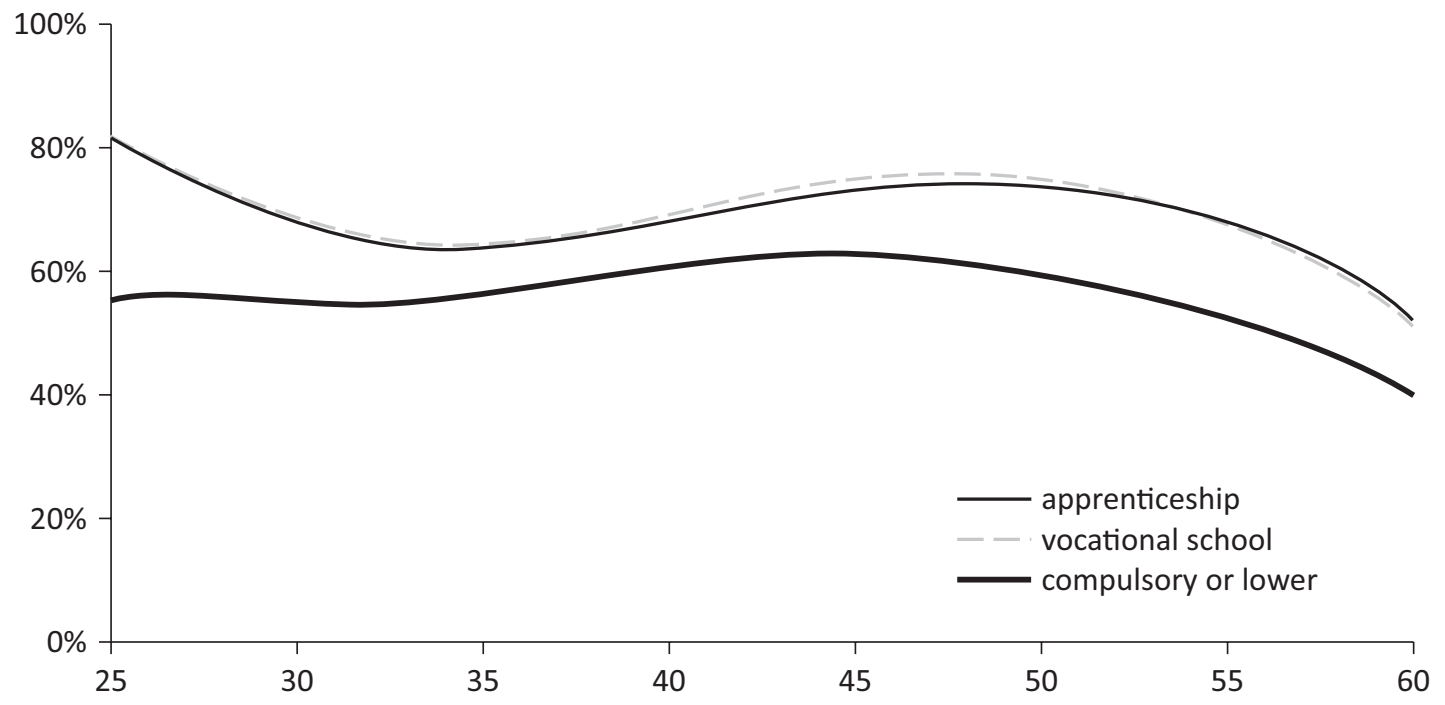

Figure A5. Employment rate (minimun 8 hours per week) by type of upper-secondary vocational education. WomenSwitzerland. Source: Swiss Labour Force Survey 1991-2014. 

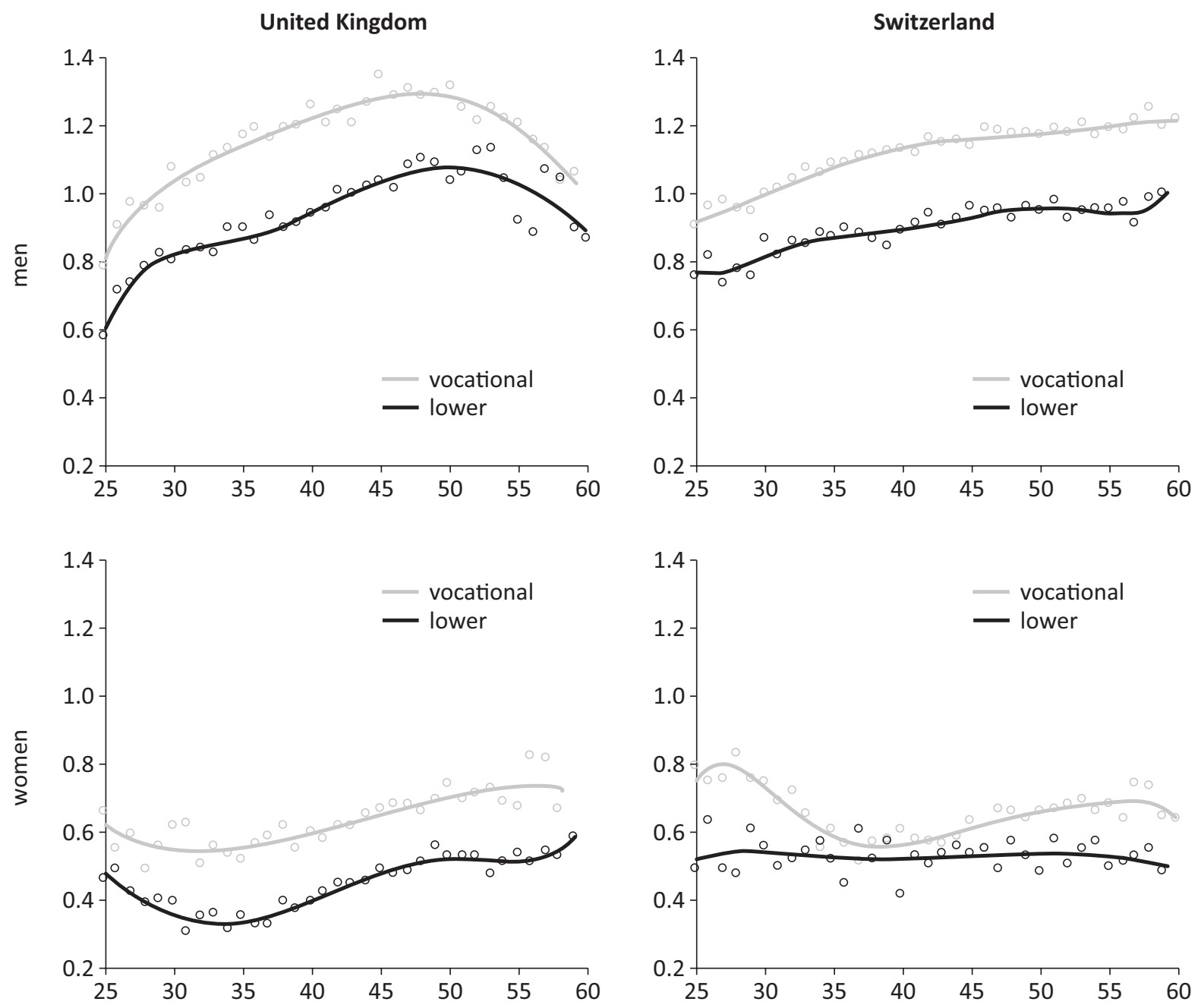

Figure A6. Median annual work income for men and women by level of education: upper-secondary vocational education (vocational) and compulsory school level or lower (lower). Source: UK Labour Force Survey 1993-2014 and Swiss Labour Force Survey 1991-2014, cohort 1954-1968. It is of little interest to compare absolute wages between the United Kingdom and Switzerland, since the purchasing power and tax systems are different. For this reason, we do not present wages in real pounds or Swiss francs, but the wages relative to the national median wage in each country. The median annual wage for the cohort 1954-1968 corrected for inflation (expressed in 2010 values) is $£ 21,025$ in the United Kingdom for the period 1993-2014, and CHF72,300 in Switzerland for 1991-2014. These amounts represent the benchmarks in each country (e.g., value of one). 


\section{COGITATIO}

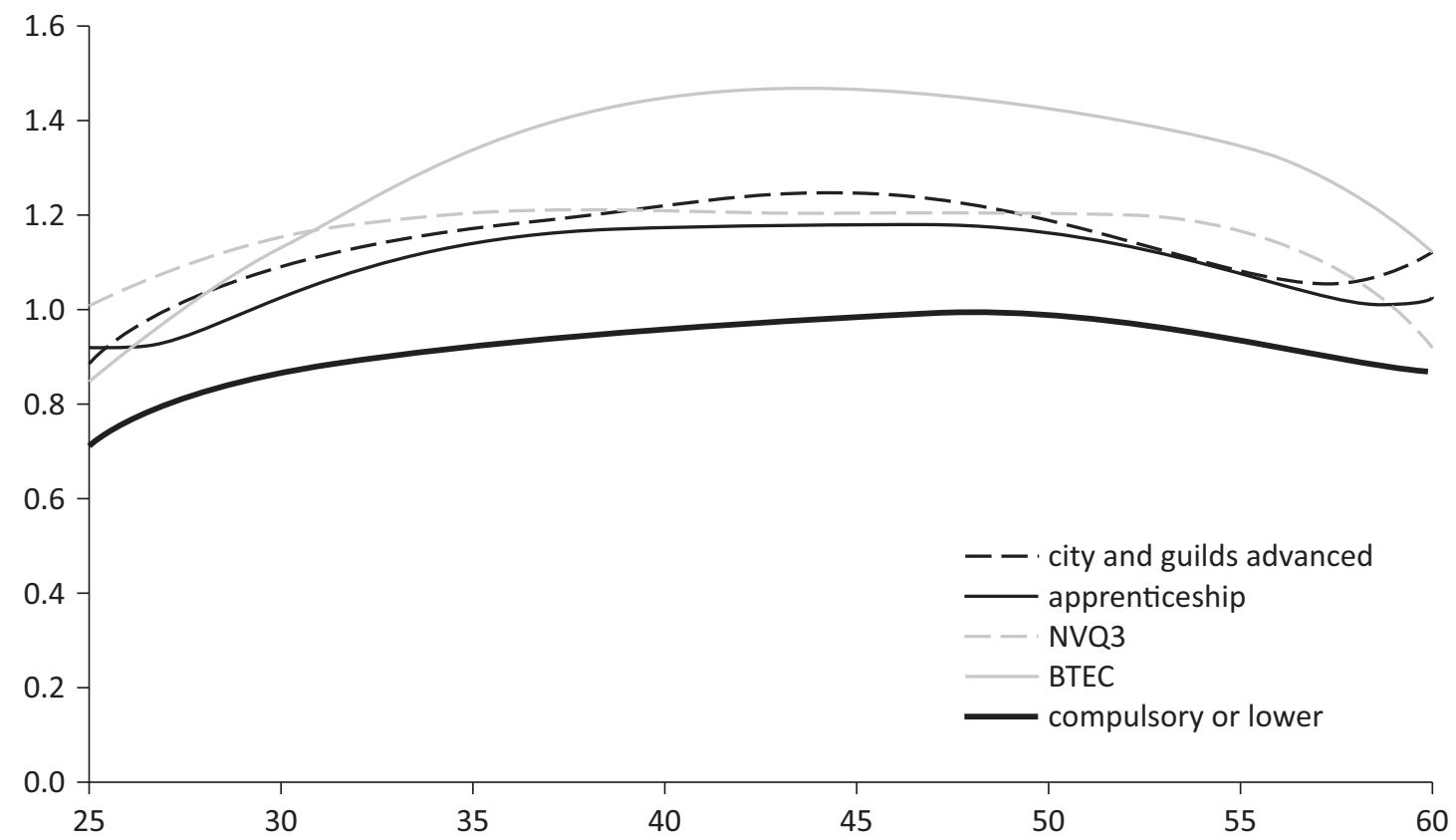

Figure A7. Median annual work income by type of upper-secondary vocational education. Men-United Kingdom. Source: UK Labour Force Survey 1993-2014. Note: 1 = Median annual income for UK (£21,025).

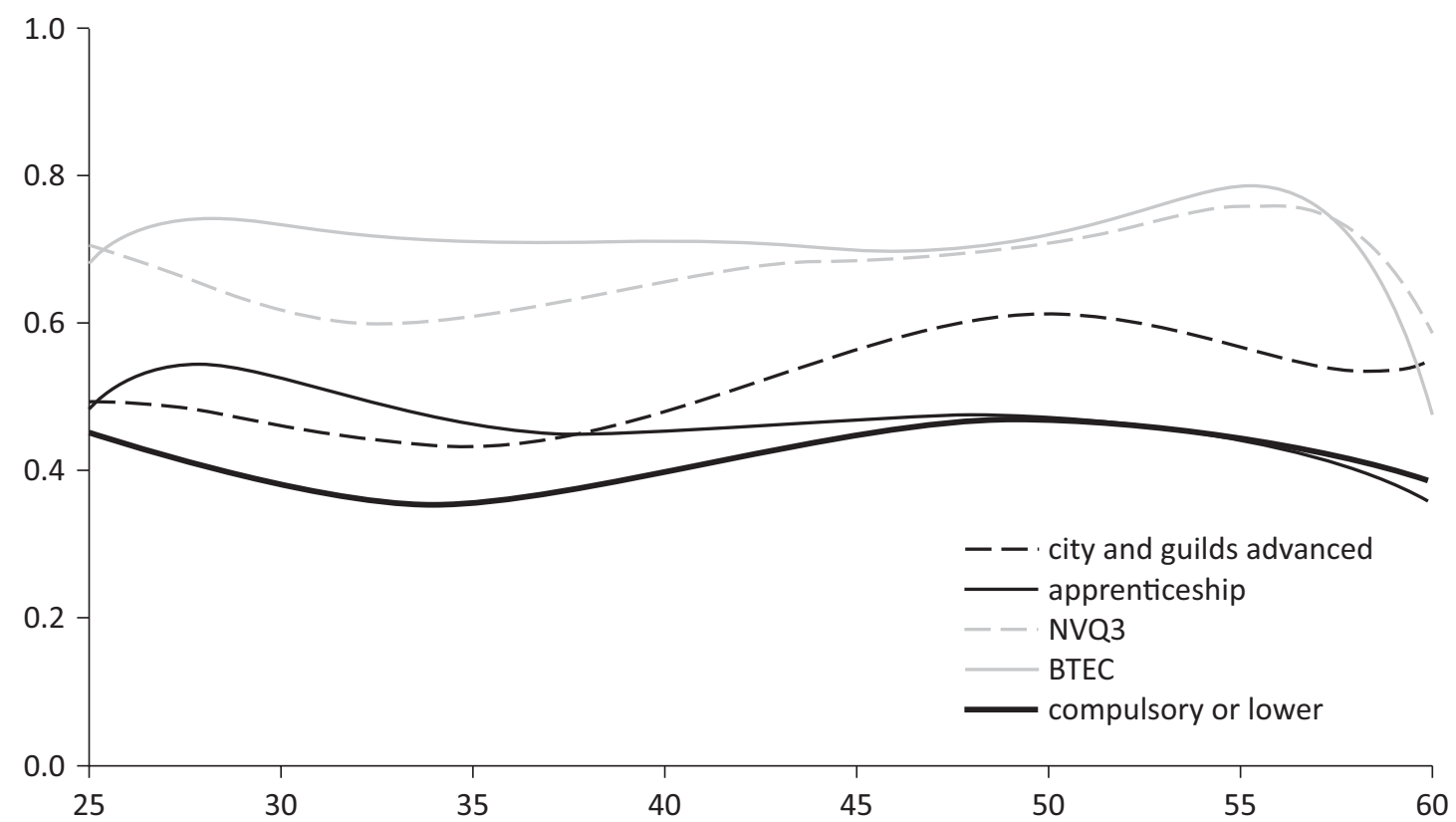

Figure A8. Median annual work income by type of upper-secondary vocational education. Women-United Kingdom. Source: UK Labour Force Survey 1993-2014. Note: 1 = Median annual income for UK $(£ 21,025)$. 


\section{COGITATIO}

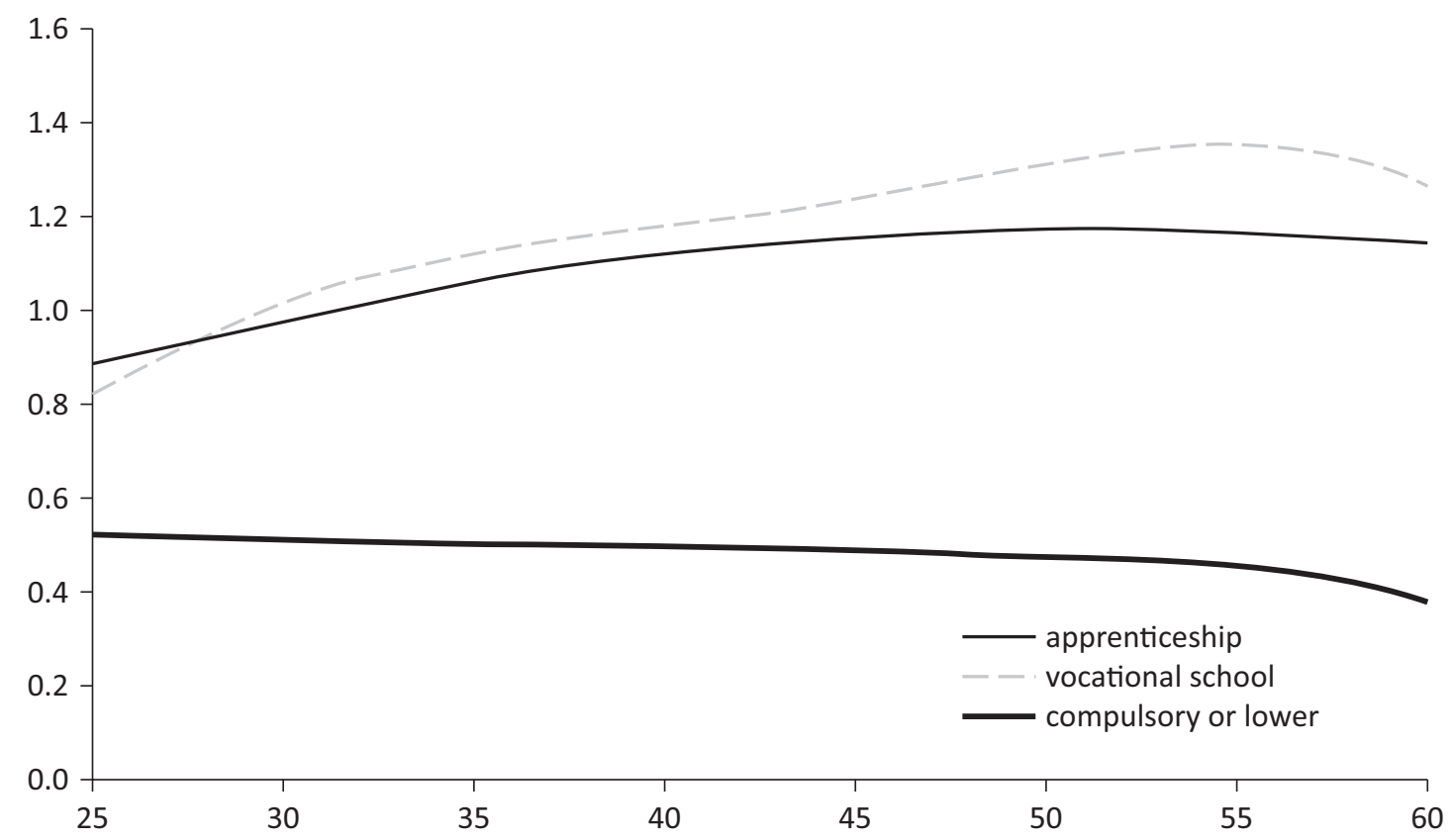

Figure A9. Median annual work income by type of upper-secondary vocational education. Men-Switzerland. Source: Swiss Labour Force Survey 1991-2014. Note: 1 = Median annual work income for CH (CHF72,300).

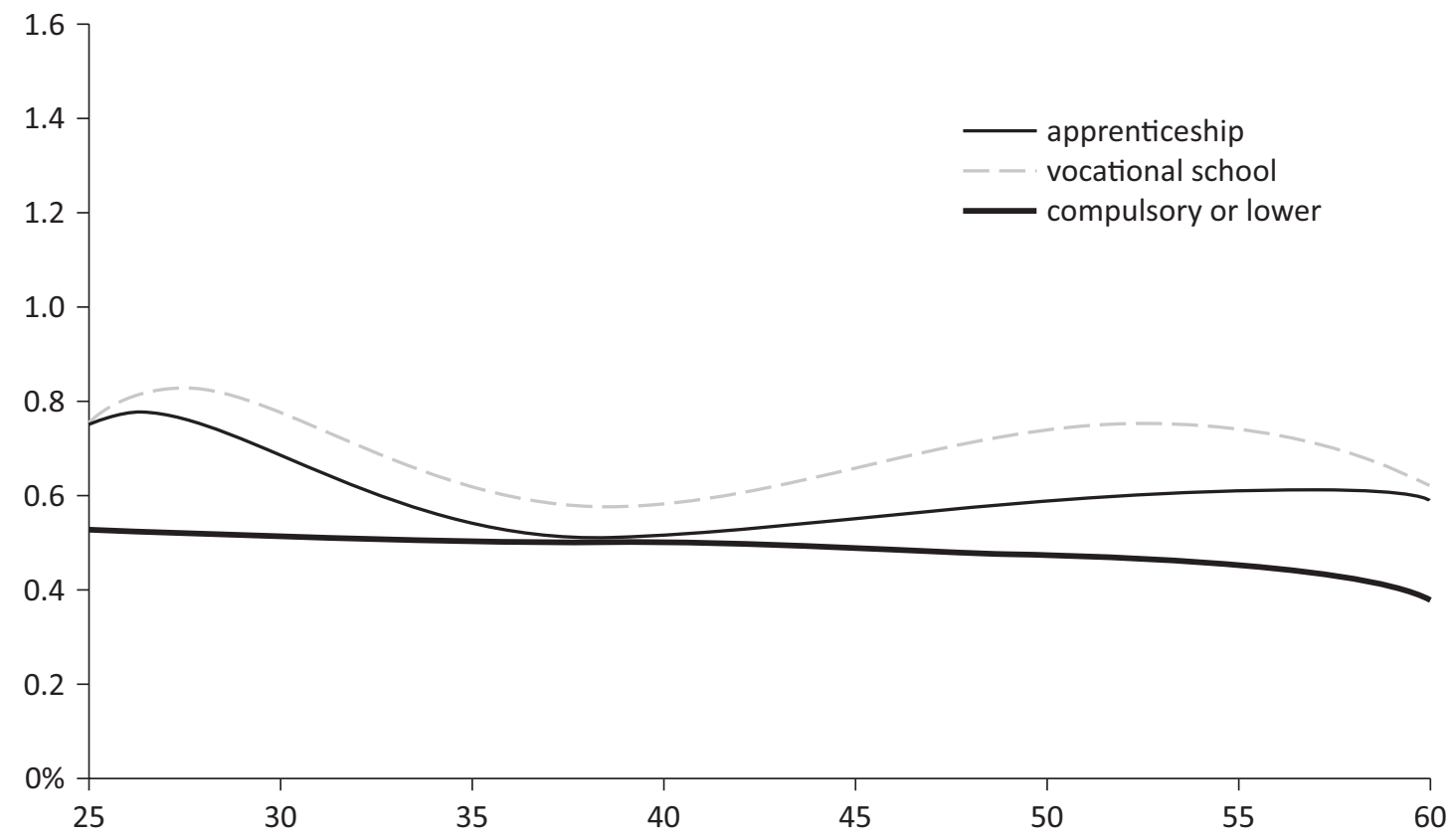

Figure A10. Median annual work income by type of upper-secondary vocational education. Women-Switzerland. Source: Swiss Labour Force Survey 1991-2014. Note: 1 = Median annual work income for CH (CHF72,300). 

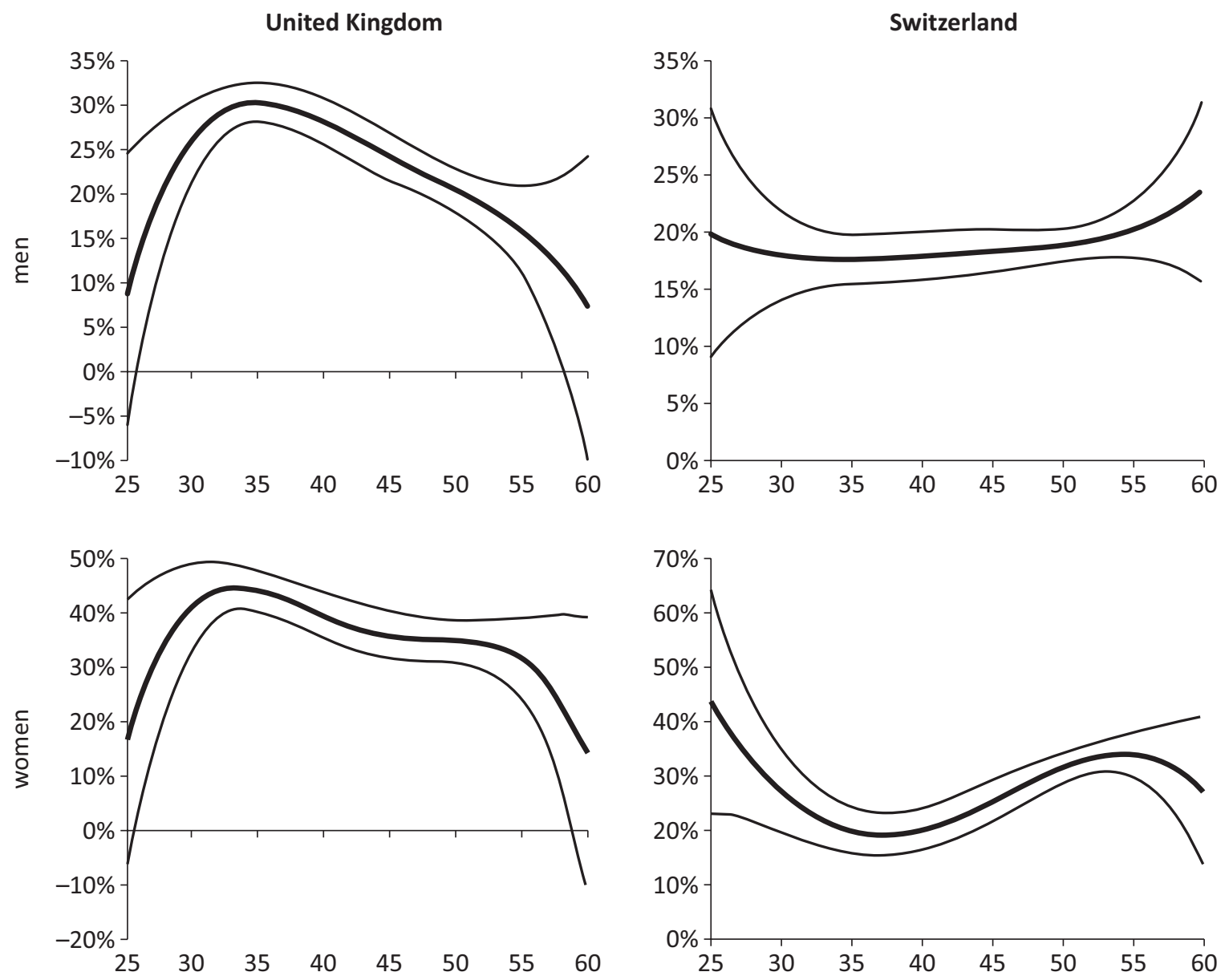

Figure A11. Difference in annual wages by age for upper-secondary vocational relative to lower education (average marginal effects). Source: UK Labour Force Survey 1993-2014 and Swiss Labour Force Survey 1991-2014, cohort 1954-1968. Note: Main line stands for average marginal effect; thinner lines stands for $95 \%$ confidence intervals. 
Tables

Table A1. Definition of educational categories, United Kingdom and Switzerland.

\begin{tabular}{lll}
\hline & United Kingdom & Switzerland \\
\hline Tertiary & $\begin{array}{l}\text { higher education below degree, } \\
\text { degree or higher }\end{array}$ & $\begin{array}{l}\text { university, technical college and } \\
\text { tertiary vocational education }\end{array}$ \\
\hline Upper-secondary & $\begin{array}{l}\text { A level or equivalent, apprenticeship } \\
\text { above foundation level, city and } \\
\text { guilds advanced craft and similar }\end{array}$ & $\begin{array}{l}\text { apprenticeship and } \\
\text { baccalaureate }\end{array}$ \\
\hline Intermediate & $\begin{array}{l}\text { GCSE A-C or equivalent, apprenticeship } \\
\text { foundation level, city and guilds craft } \\
\text { secondary }\end{array}$ & one or two years of internship \\
& primary/compulsory school, unfinished school and no qualifications
\end{tabular}

Table A2. OLS regression coefficients for being in employment (minimum 8 hours per week). Source: UK Labour Force Survey 1993-2014 and Swiss Labour Force Survey 1991-2014, cohort 1954-1968.

\begin{tabular}{|c|c|c|c|c|c|}
\hline & & \multicolumn{2}{|c|}{ men } & \multicolumn{2}{|c|}{ women } \\
\hline & & estimate & std. e & estimate & std. e \\
\hline \multirow[t]{12}{*}{ UK Labour Force Survey } & age & 0.919 & 0.817 & -3.751 & 0.917 \\
\hline & age $^{2}$ & -0.364 & 0.301 & 1.418 & 0.338 \\
\hline & $\operatorname{age}^{3}$ & 0.068 & 0.048 & -0.221 & 0.054 \\
\hline & age $^{4}$ & -0.005 & 0.003 & 0.012 & 0.003 \\
\hline & educ: voc & -1.126 & 1.197 & 1.582 & 1.820 \\
\hline & age*educ: voc & 1.327 & 1.200 & -0.765 & 1.827 \\
\hline & age $^{2 *}$ educ: voc & -0.487 & 0.443 & 0.061 & 0.674 \\
\hline & age $^{3 *}$ educ: voc & 0.077 & 0.071 & 0.024 & 0.109 \\
\hline & age $^{4 *}$ educ: voc & -0.004 & 0.004 & -0.003 & 0.006 \\
\hline & constant & -0.371 & 0.816 & 3.745 & 0.915 \\
\hline & Adjusted $\mathrm{R}^{2}$ & \multicolumn{2}{|c|}{0.077} & \multicolumn{2}{|c|}{0.077} \\
\hline & $\mathrm{N}$ & \multicolumn{2}{|c|}{114,198} & \multicolumn{2}{|c|}{98,969} \\
\hline \multirow[t]{12}{*}{ Swiss Labour Force Survey } & age & 1.708 & 2.041 & -4.690 & 2.468 \\
\hline & $\operatorname{age}^{2}$ & -0.684 & 0.731 & 1.726 & 0.886 \\
\hline & $\operatorname{age}^{3}$ & 0.116 & 0.114 & -0.268 & 0.139 \\
\hline & age $^{4}$ & -0.007 & 0.007 & 0.015 & 0.008 \\
\hline & educ: voc & 1.377 & 2.280 & 2.531 & 2.858 \\
\hline & age*educ: voc & -1.645 & 2.229 & -1.712 & 2.804 \\
\hline & $\operatorname{age}^{2 *}$ educ: voc & 0.688 & 0.802 & 0.354 & 1.011 \\
\hline & age $^{3 *}$ educ: voc & -0.120 & 0.126 & -0.015 & 0.159 \\
\hline & age $^{4 *}$ educ: voc & 0.008 & 0.007 & -0.001 & 0.009 \\
\hline & constant & -0.551 & 2.095 & 5.150 & 2.527 \\
\hline & Adjusted $\mathrm{R}^{2}$ & \multicolumn{2}{|c|}{0.057} & \multicolumn{2}{|c|}{0.041} \\
\hline & $\mathrm{N}$ & \multicolumn{2}{|c|}{32,869} & \multicolumn{2}{|c|}{38,858} \\
\hline
\end{tabular}

Notes: Controls include region and nationality. Age variables have been divided by 10 (i.e., age 25 is expressed as 2.5 , age 45 as 4.5 ). Coefficients in bold are significant at $p<0.05$. 
Table A3. OLS regression coefficients for log hourly wage. Source: UK Labour Force Survey 1993-2014 and Swiss Labour Force Survey 1991-2014, cohort 1954-1968.

\begin{tabular}{|c|c|c|c|c|c|}
\hline & & \multicolumn{2}{|c|}{ men } & \multicolumn{2}{|c|}{ women } \\
\hline & & estimate & std. e & estimate & std. e \\
\hline \multirow[t]{12}{*}{ UK Labour Force Survey } & age & 6.065 & 2.476 & 0.628 & 2.157 \\
\hline & age $^{2}$ & -2.239 & 0.903 & -0.480 & 0.786 \\
\hline & age $^{3}$ & 0.375 & 0.144 & 0.121 & 0.125 \\
\hline & age $^{4}$ & -0.023 & 0.008 & -0.010 & 0.007 \\
\hline & educ: voc & -2.850 & 3.504 & -3.204 & 3.627 \\
\hline & age*educ: voc & 2.767 & 3.473 & 2.644 & 3.585 \\
\hline & age $^{2 *}$ educ: voc & -0.911 & 1.269 & -0.709 & 1.306 \\
\hline & age $^{3 *}$ educ: voc & 0.131 & 0.203 & 0.077 & 0.208 \\
\hline & age $^{4 *}$ educ: voc & -0.007 & 0.012 & -0.003 & 0.012 \\
\hline & constant & -4.262 & 2.501 & 1.720 & 2.183 \\
\hline & Adjusted $\mathrm{R}^{2}$ & \multicolumn{2}{|c|}{0.125} & \multicolumn{2}{|c|}{0.157} \\
\hline & $\mathrm{N}$ & \multicolumn{2}{|c|}{18,542} & \multicolumn{2}{|c|}{14,042} \\
\hline \multirow[t]{12}{*}{ Swiss Labour Force Survey } & age 4.300 & 2.480 & 1.432 & 2.680 & \\
\hline & age $^{2}$ & -1.403 & 0.891 & -0.448 & 0.959 \\
\hline & $\operatorname{age}^{3}$ & 0.206 & 0.140 & 0.065 & 0.150 \\
\hline & age $^{4}$ & -0.011 & 0.008 & -0.004 & 0.009 \\
\hline & educ: voc & 4.817 & 2.739 & 0.193 & 3.043 \\
\hline & age*educ: voc & -4.850 & 2.684 & -0.123 & 2.972 \\
\hline & age $^{2 *}$ educ: voc & 1.820 & 0.968 & 0.075 & 1.068 \\
\hline & age $^{3 *}$ educ: voc & -0.295 & 0.152 & -0.015 & 0.167 \\
\hline & age $^{4 *}$ educ: voc & 0.018 & 0.009 & 0.001 & 0.010 \\
\hline & constant & -1.339 & 2.540 & 1.623 & 2.756 \\
\hline & Adjusted $\mathrm{R}^{2}$ & \multicolumn{2}{|c|}{0.191} & \multicolumn{2}{|c|}{0.146} \\
\hline & $\mathrm{N}$ & \multicolumn{2}{|c|}{21,452} & \multicolumn{2}{|c|}{21,249} \\
\hline
\end{tabular}

Notes: Controls include region and nationality. Age variables have been divided by 10 (i.e., age 25 is expressed as 2.5 , age 45 as 4.5 ). Coefficients in bold are significant at $p<0.05$. 